\title{
Identification of candidate genes related to salt tolerance of the secretohalophyte Atriplex canescens by transcriptomic analysis
}

\author{
Huan Guo, Le Zhang, Yan-Nong Cui, Suo-Min Wang and Ai-Ke Bao* [D
}

\begin{abstract}
Background: Atriplex canescens is a typical $\mathrm{C}_{4}$ secretohalophyte with salt bladders on the leaves. Accumulating excessive $\mathrm{Na}^{+}$in tissues and salt bladders, maintaining intracellular $\mathrm{K}^{+}$homeostasis and increasing leaf organic solutes are crucial for $A$. canescens survival in harsh saline environments, and enhanced photosynthetic activity and water balance promote its adaptation to salt. However, the molecular basis for these physiological mechanisms is poorly understood. Four-week-old A. canescens seedlings were treated with $100 \mathrm{mM} \mathrm{NaCl}$ for 6 and $24 \mathrm{~h}$, and differentially expressed genes in leaves and roots were identified, respectively, with Illumina sequencing.

Results: In A. canescens treated with $100 \mathrm{mM} \mathrm{NaCl}$, the transcripts of genes encoding transporters/channels for important nutrient elements, which affect growth under salinity, significantly increased, and genes involved in exclusion, uptake and vacuolar compartmentalization of $\mathrm{Na}^{+}$in leaves might play vital roles in $\mathrm{Na}^{+}$accumulation in salt bladders. Moreover, $\mathrm{NaCl}$ treatment upregulated the transcripts of key genes related to leaf organic osmolytes synthesis, which are conducive to osmotic adjustment. Correspondingly, aquaporin-encoding genes in leaves showed increased transcripts under $\mathrm{NaCl}$ treatment, which might facilitate water balance maintenance of $A$. canescens seedlings in a low water potential condition. Additionally, the transcripts of many genes involved in photosynthetic electron transport and the $C_{4}$ pathway was rapidly induced, while other genes related to chlorophyll biosynthesis, electron transport and $C_{3}$ carbon fixation were later upregulated by $100 \mathrm{mM} \mathrm{NaCl}$.

Conclusions: We identified many important candidate genes involved in the primary physiological mechanisms of A. canescens salt tolerance. This study provides excellent gene resources for genetic improvement of salt tolerance of important crops and forages.
\end{abstract}

Keywords: Halophyte, Atriplex canescens, Salt tolerance, Transcriptomic analysis, Differentially expressed gene

\section{Background}

Salinity is one of the most severe abiotic factors threatening agricultural productivity and ecological environment throughout the world $[2,12]$. Approximately half of irrigated lands in the world are threatened by salinity [43]. The expansion of soil salinization and the increasing human population are forcing agricultural production into marginal areas [44]. Soil salinization can

\footnotetext{
* Correspondence: baoaik@lzu.edu.cn

State Key Laboratory of Grassland Agro-ecosystems, Key Laboratory of Grassland Livestock Industry Innovation, Ministry of Agriculture and Rural Affairs, College of Pastoral Agriculture Science and Technology, Lanzhou University, Lanzhou 730020, People's Republic of China
}

significantly reduce the yield and quality of crops by resulting in a series of metabolic disturbances due to ionic toxicity, physiological drought and nutrient deficiency $[14,63]$. Therefore, improving the salt tolerance of plants, especially traditional crops and forages, is currently an urgent issue, since most of these species are glycophytes with weak salt tolerance $[43,51]$. In contrast, halophytic species have evolved multiple adaptation strategies to deal with harsh saline environments $[12,44]$. Learning from halophytes, understanding the mechanisms underlying plant response to salinity and thereby identifying key genes related to salt tolerance

(c) The Author(s). 2019 Open Access This article is distributed under the terms of the Creative Commons Attribution 4.0 International License (http://creativecommons.org/licenses/by/4.0/), which permits unrestricted use, distribution, and reproduction in any medium, provided you give appropriate credit to the original author(s) and the source, provide a link to the Creative Commons license, and indicate if changes were made. The Creative Commons Public Domain Dedication waiver (http://creativecommons.org/publicdomain/zero/1.0/) applies to the data made available in this article, unless otherwise stated. 
will contribute to breeding crops with salt tolerance [61].

Halophytes can be divided into three types based on their adaptive strategies to saline environments: (i) pseudohalophytes maintain a low $\mathrm{Na}^{+}$level by limiting $\mathrm{Na}^{+}$ uptake [52], (ii) euhalophytes compartmentalize $\mathrm{Na}^{+}$into swollen internal vacuoles to alleviate $\mathrm{Na}^{+}$toxicity in the cytosol $[14,56]$ and (iii) secretohalophytes exclude excessive $\mathrm{Na}^{+}$from secreting structures (salt glands or salt bladders) on the surface of stems and/or leaves [11, 44]. For example, Reaumuria trigyna and Limonium bicolor are capable of secreting $\mathrm{Na}^{+}$via their multicellular salt glands, but excreting little $\mathrm{K}^{+}$to maintain high $\mathrm{K}^{+} / \mathrm{Na}^{+}$ ratio in the shoots $[8,62]$. Mesembryanthemum crystallinum, Chenopodium quinoa and Atriplex species deposit a large amount of $\mathrm{Na}^{+}$in epidermal bladder cells (EBCs) to improve salt tolerance of plants [26, 39]. Approximately half of all halophyte plants possess salt bladders, which segregate excessive $\mathrm{Na}^{+}$away from metabolically active organs in the growing plant body [13, 44]; hence, these plants are likely to be potential species for saline soil amelioration and improvement of salt tolerance in important crops.

Atriplex canescens (four-wing saltbush), a $\mathrm{C}_{4}$ perennial semi-evergreen woody shrub with excellent adaptability to salinity and drought, is a typical secretohalophyte with salt bladders that is widely distributed in saline and arid regions [22]. This species is commonly planted in highway medians and on road shoulders, slopes, and other disturbed areas for erosion control and reclamation of marginal lands, and it can be used as a landscape plant in the arid regions of northern China; moreover, A. canescens is an attractive fodder crop for most livestock because of its high palatability and nutritional value $[17,40]$. Early research findings showed that A. canescens could grow along a salinity gradient from 72 to $2017 \mathrm{~mol} / \mathrm{m}^{3} \mathrm{NaCl}$ in the root zone and accumulated more $\mathrm{Na}^{+}$than $\mathrm{K}^{+}$for osmotic adjustment (OA) at relatively low salinities $[17,18]$. Our previous study revealed that moderate salinity $(100 \mathrm{mM} \mathrm{NaCl})$ could stimulate the growth of $A$. canescens and high salinity $(400 \mathrm{mM} \mathrm{NaCl})$ had no significant effect on its growth [40]. Under saline conditions, A. canescens can enhance photosynthetic capacity, accumulate more $\mathrm{Na}^{+}$in tissues and salt bladders, maintain leaf $\mathrm{K}^{+}$homeostasis, and use inorganic ions as well as organic osmolytes for OA, which may contribute to water balance in the plant [40]. Our latest investigation showed that the addition of 100 $\mathrm{mM} \mathrm{NaCl}$ effectively alleviated the adverse impact of drought on the growth of $A$. canescens by increasing the accumulation of solutes $\left(\mathrm{Na}^{+}\right.$, free proline, betaine and soluble sugar) in leaves as well as the net photosynthetic rate and water content (Guo H. and Bao A.K., unpublished data). All of these results indicate that the transport of $\mathrm{Na}^{+}$and $\mathrm{K}^{+}$, the accumulation of organic solutes, the improvement of photosynthetic activity and leaf hydration are vital strategies for $A$. canescens adaptation to saline environments. Nonetheless, the possible molecular basis of these important physiological mechanisms is poorly understood owing to the absence of genomic data in A. canescens.

High-throughput RNA sequencing has been widely used to investigate the molecular processes related to adaptive responses to abiotic stresses and to identify stress-resistance candidate genes by analyzing differences in transcript abundance [57]. In this work, transcriptomes of $A$. canescens were generated by Illumina assembly technology to lay the foundation for exploring the potential salt tolerance mechanisms of this species. In addition, the genes showing significant transcriptional changes in $A$. canescens under $\mathrm{NaCl}$ treatment were then identified by comparing the gene transcript profiles in leaves and roots between salt-treated and control plants by using a tag-based digital gene expression (DGE) system, mainly focusing on identifying the candidate genes related to ion transport, organic osmolyte accumulation, water transport and photosynthesis.

\section{Results}

\section{Transcriptome sequencing, de novo assembly and} unigene functional annotation

A total of 13.37 and $13.41 \mathrm{~Gb}$ clean bases were generated from the leaves and roots of $A$. canescens by Illumina HiSeq sequencing, respectively (Additional file 1: Table S1). Then, 207.20 Mb raw reads were yielded from leaves and $210.00 \mathrm{Mb}$ raw reads were yielded from roots through high-throughput sequencing (Additional file 1: Table S1). After filtering, a total of 133.70 and 134.12 $\mathrm{Mb}$ clean reads were generated from the leaves and roots, respectively, coupled with a Q20 score greater than 97 and $0.00 \%$ Ns (Additional file 1: Table S1). All of these results indicated that the output and quality of transcriptome sequencing were adequate for subsequent analysis.

Paired-end information was used to join contigs into scaffolds and further assembly ${ }^{23}$, and 54,611 and 59,582 unigenes, with a mean length of 912 and $696 \mathrm{bp}$, respectively, were generated from the leaves and roots (Table 1 ). Then, 70,571 all-unigene sequences were acquired, with a mean length of $961 \mathrm{bp}$, N50 of $1647 \mathrm{bp}$ and GC percentage of $40.01 \%$, after further assembly of the unigenes from leaves and roots (Table 1). The size distribution is shown in Additional file 1: Figure S1, and the lengths of 24,205 unigenes were more than $1000 \mathrm{bp}$.

Then, 44,121 unigenes (62.52\% of the 70,571 unigenes) were annotated to known genes in 7 databases, namely, the Nr, Nt, Swiss-Prot, KEGG, COG, InterPro and GO databases (Additional file 1: Table S2). Functional 
Table 1 Overview of de novo sequence assembly

\begin{tabular}{llllll}
\hline Unigenes & Total number & Total length $(\mathrm{bp})$ & Mean length (bp) & N50 (bp) & GC (\%) \\
\hline Leaves & 54,611 & $49,833,011$ & 912 & 1547 & 40.21 \\
Roots & 59,582 & $76,399,446$ & 696 & 1332 & 40.19 \\
All & 70,571 & $67,859,996$ & 961 & 1647 & 40.01 \\
\hline
\end{tabular}

annotation was not obtained for $37.48 \%$ of the unigenes due to the absence of genomic data in A. canescens and close-related species. Among these annotated unigenes, 26,021 unigenes annotated in the COG database in terms of sequence homology were classified into 25 functional clusters and 37,395 unigenes annotated with GO terms were grouped into 3 main GO categories with 52 subcategories (Additional file 1:Figures S2 and S3).

\section{Differentially expressed genes (DEGs) in A. canescens under $\mathrm{NaCl}$ treatment}

Eight independent cDNA libraries (CL6, CR6, SL6, SR6, CL24, CR24, SL24 and SR24) were sequenced, and approximately 22 million raw reads were generated in each library; after filtering low-quality reads, we obtained 21 million clean reads in each library (data not shown), more than $72 \%$ of which could be mapped to the transcriptome reference database (data not shown).

The DEGs in $A$. canescens were analyzed by comparing the $100 \mathrm{mM} \mathrm{NaCl}$ treatment with the control. When plants were subjected to the $100 \mathrm{mM} \mathrm{NaCl}$ treatment for $6 \mathrm{~h}, 14,686$ and 16,306 DEGs were found in the leaves and roots, respectively, using the thresholds of FDR < 0.001 and $\mid \log _{2}$ Ratio $\mid>1$ (Fig. 1). Among these DEGs, 9023 and 4824 DEGs were upregulated, including 1768 and 1031 DEGs that were expressed in the leaves and roots of plants in the $100 \mathrm{mM} \mathrm{NaCl}$ treatment but almost not expressed in the control (the FPKM value was 0.01 in control plants, the same below), respectively (Fig. 1). Interestingly, the number of upregulated DEGs was much greater than that of downregulated DEGs in the leaves; conversely, the number of upregulated DEGs was much lower than that of downregulated DEGs in the roots. In addition, 3403 and 2405 DEGs (including 1799 and 1196 upregulated DEGs) were identified in the leaves and roots of plants treated to $100 \mathrm{mM} \mathrm{NaCl}$ for $24 \mathrm{~h}$, respectively, which was far fewer than the number identified in plants exposed to the treatment for $6 \mathrm{~h}$. Among these upregulated DEGs, 629 and 426 DEGs were expressed in the leaves and roots of plants in the $100 \mathrm{mM} \mathrm{NaCl}$ treatment while almost not expressed in the control, respectively (Fig. 1).

\section{DEGs related to ion, glucose and oxygen transport}

Firstly, the DEGs related to ion transport especially $\mathrm{Na}^{+}$ transport into salt bladders were identified under 100 $\mathrm{mM} \mathrm{NaCl}$ treatment since accumulating a great quantity of $\mathrm{Na}^{+}$in salt bladders and maintaining intracellular ion homeostasis are vital strategies for $A$. canescens adaptation to saline conditions.

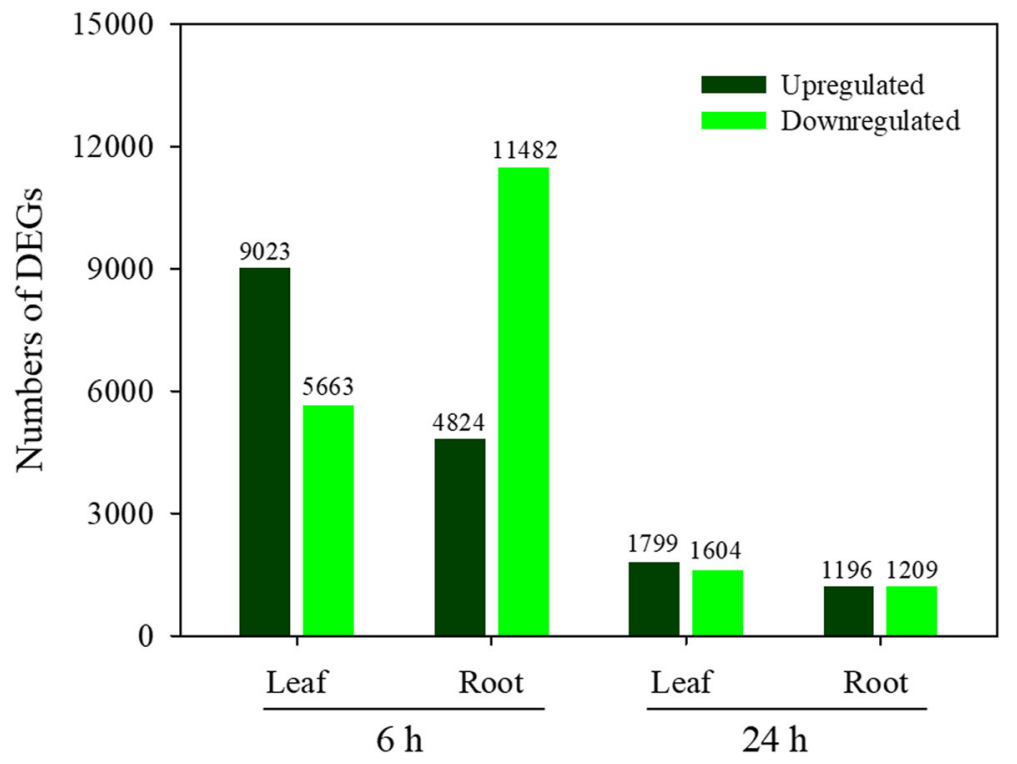

Fig. 1 Numbers of differentially expressed genes (DEGs) in leaves and roots of A. canescens under $100 \mathrm{mM} \mathrm{NaCl}$ for 6 and $24 \mathrm{~h}$. A FDR $<0.001$ and an absolute value of the $\log _{2}$ Ratio $>1$ were used as the thresholds to determine significant differences in gene expression 
In leaves, the number of upregulated DEGs associated with ion transport was much larger than that of downregulated DEGs when plants were treated with $100 \mathrm{mM}$ $\mathrm{NaCl}$ for either $6 \mathrm{~h}$ or $24 \mathrm{~h}$ (Fig. 2). After plants were treated with $100 \mathrm{mM} \mathrm{NaCl}$ for $6 \mathrm{~h}, 76$ DEGs were upregulated, which included important transcripts related to $\mathrm{Na}^{+}$(including $N H X$ and $H K T$ ), $\mathrm{K}^{+}$(such as $A K T$ and SKOR), $\mathrm{Ca}^{2+}$ (CNGC, CCX and $P-C a^{2+}$ ATPase), $\mathrm{Mg}^{2+}$ $(M G T)$, and $\mathrm{NH}_{4}{ }^{+}(A M T)$ transport and the anion transport of $\mathrm{NO}^{3-}\left(\right.$ NRT) $, \mathrm{PO}_{4}{ }^{3-}(P H T), \mathrm{SO}_{4}{ }^{2-}$ (STAS), $\mathrm{Cl}^{-}$ $(C L C$ and $S L A H)$ and several important micronutrients (such as $\mathrm{Zn}, \mathrm{Mo}, \mathrm{B}$ and $\mathrm{Cu}$ ) (Fig. 2a; Additional file 1: Table S3). Some genes encoding plasma membrane $\mathrm{H}^{+}$-ATPases (P- $\mathrm{H}^{+}$ATPase) and vacuolar $\mathrm{H}^{+}$-pyrophosphatases $\left(\mathrm{V}-\mathrm{H}^{+}\right.$PPase) were also upregulated (Fig. 2a). The number of DEGs was significantly lower under 100 $\mathrm{mM} \mathrm{NaCl}$ for $24 \mathrm{~h}$ than under $100 \mathrm{mM} \mathrm{NaCl}$ for $6 \mathrm{~h}$
(Fig. 2b). Among these upregulated genes, two transcripts associated with $\mathrm{Na}^{+}$transport (SOS1 and HKT1) were upregulated, and the other upregulated DEGs were mainly SKOR, AKT, CNGC, MGT and NRT transport protein family genes, which are related to nutrient element transport (Fig. 2b; Additional file 1: Table S4). In addition, among these DEGs related to $\mathrm{K}^{+}$transport in leaves, 9 DEGs were significantly upregulated under 100 $\mathrm{mM} \mathrm{NaCl}$ but not under control conditions for either 6 or $24 \mathrm{~h}$ (Table 2).

The epidermal bladder cell (EBC) together with stalk cell (SC) and epidermal cell (EC) constitute the EC-SC-EBC complex [44]. The $\mathrm{Na}^{+}$sequestration in the high vacuolization of salt bladder is achieved by four times $\mathrm{Na}^{+}$transport through plasma membrane and one time $\mathrm{Na}^{+}$transport through tonoplast [65]. A latest study on another halophyte $C$. quinoa has proposed that

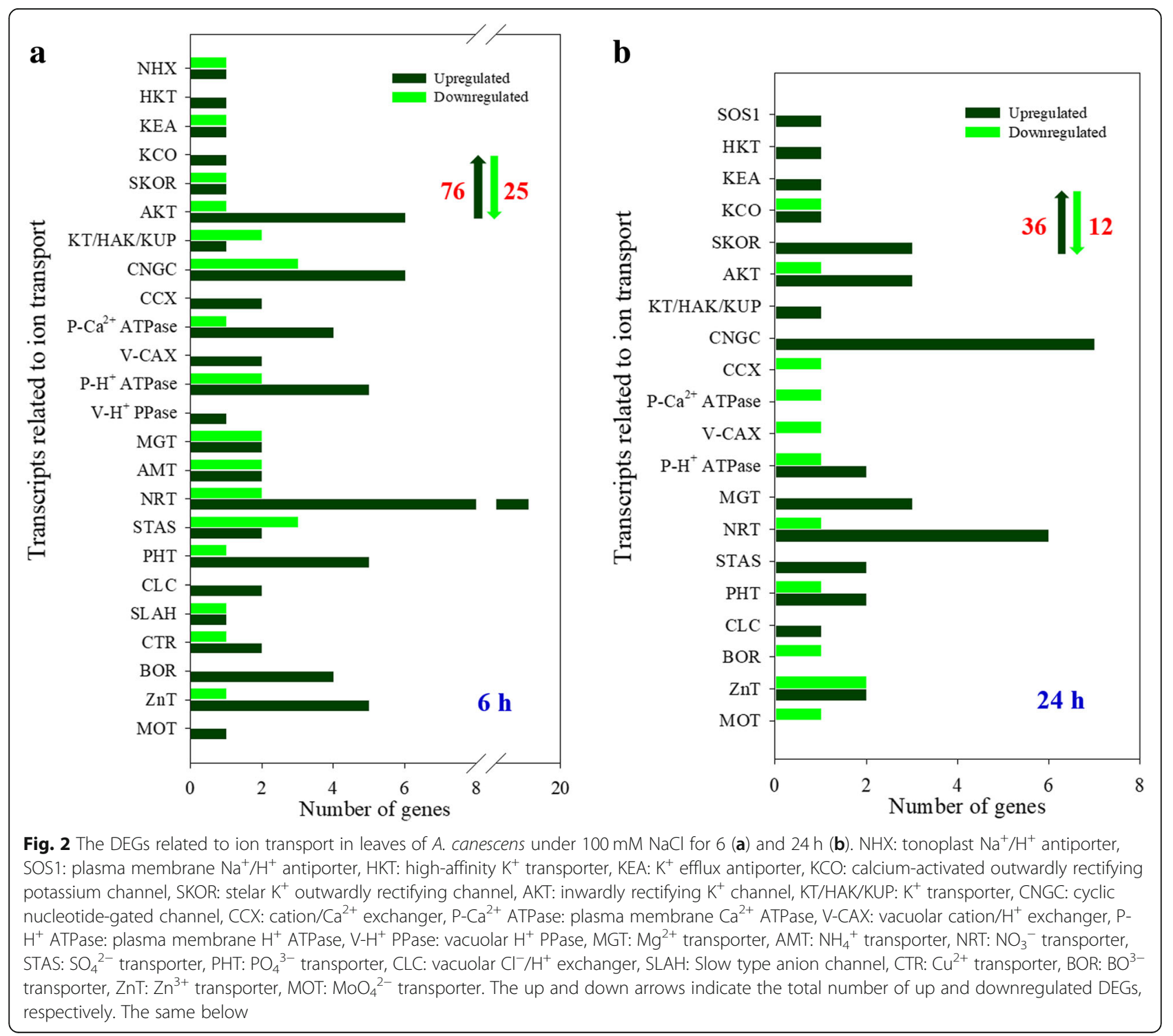


Table 2 The upregulated DEGs related to $\mathrm{K}^{+}$transport in roots and leaves of $A$. canescens under $100 \mathrm{mM} \mathrm{NaCl}$ but not under control condition for either 6 or $24 \mathrm{~h}$

\begin{tabular}{|c|c|c|c|}
\hline \multicolumn{2}{|l|}{ Roots } & \multicolumn{2}{|l|}{ Leaves } \\
\hline Gene ID & Homologous gene & Gene ID & Homologous gene \\
\hline CL5980.Contig1_All & Potassium channel AKT2/3 & Unigene23528_All & Potassium channel AKT1 \\
\hline CL6985.Contig2_All & Inwardly rectifying $\mathrm{K}^{+}$channel AKT1 & Unigene25880_All & Potassium channel AKT1 \\
\hline Unigene23969_All & Potassium channel AKT1 & CL6985.Contig2_All & Inwardly rectifying $\mathrm{K}^{+}$channel AKT1 \\
\hline Unigene39479_All & Potassium channel SKOR & Unigene39479_All & Potassium channel SKOR \\
\hline Unigene12729_All & Cyclic nucleotide-gated ion channel CNGC4 & CL7131.Contig1_All & Cyclic nucleotide-gated ion channel CNGC18 \\
\hline Unigene19313_All & Cyclic nucleotide-gated ion channel CNGC2 & CL1899.Contig4_All & Cyclic nucleotide-gated ion channel CNGC14 \\
\hline CL2081.Contig2_All & Potassium transporter HAK13 & CL2081.Contig2_All & Potassium transporter HAK13 \\
\hline \multirow[t]{2}{*}{ Unigene7902_All } & Two-pore potassium channel KCO1 & Unigene23223_All & $\begin{array}{l}\mathrm{K}^{+} \text {efflux antiporter } \\
\text { KEA2 }\end{array}$ \\
\hline & & CL6946.Contig2_All & Two-pore potassium channel KCO1 \\
\hline
\end{tabular}

the outward $\mathrm{Na}^{+}$movement across plasma membrane of EC and SC is mediated by SOS1; the inward $\mathrm{Na}^{+}$movement across plasma membrane of SC and $\mathrm{EBC}$ is mediated by $\mathrm{HKT} 1$, coupled with $\mathrm{P}-\mathrm{H}^{+}$ATPase providing proton gradients and membrane potential; the $\mathrm{Na}^{+}$ movement into vacuole of EBC is mediated by NHX, coupled with $\mathrm{V}-\mathrm{H}^{+}$PPase providing proton gradients and membrane potential [4]. Therefore, we further analyzed the transcripts pattern of SOS1, HKT1, NHX, $\mathrm{P}-\mathrm{H}^{+}$ ATPase and $V$ - $H^{+}$PPase in leaves of A. canescens exposed to $100 \mathrm{mM} \mathrm{NaCl}$ for 6 and $24 \mathrm{~h}$. The results showed that the upregulated DEGs in leaves under salt treatment included 1 SOS1, $2 H K T 1 s, 1 \mathrm{NHX}, 8 \mathrm{P}-\mathrm{H}^{+}$ ATPases and $1 \mathrm{~V}-\mathrm{H}^{+}$PPase (Fig. 3), indicating these genes may play vital roles in $\mathrm{Na}^{+}$sequestration in salt bladders of $A$. canescens. It was also demonstrated that monosaccharides are transported from mesophyll cells to bladder cells by the glucose transporters (GLUTs) and enter the tricarboxylic acid cycles, and hemoglobin (HB) is conducive to facilitate oxygen diffusion into stalk and

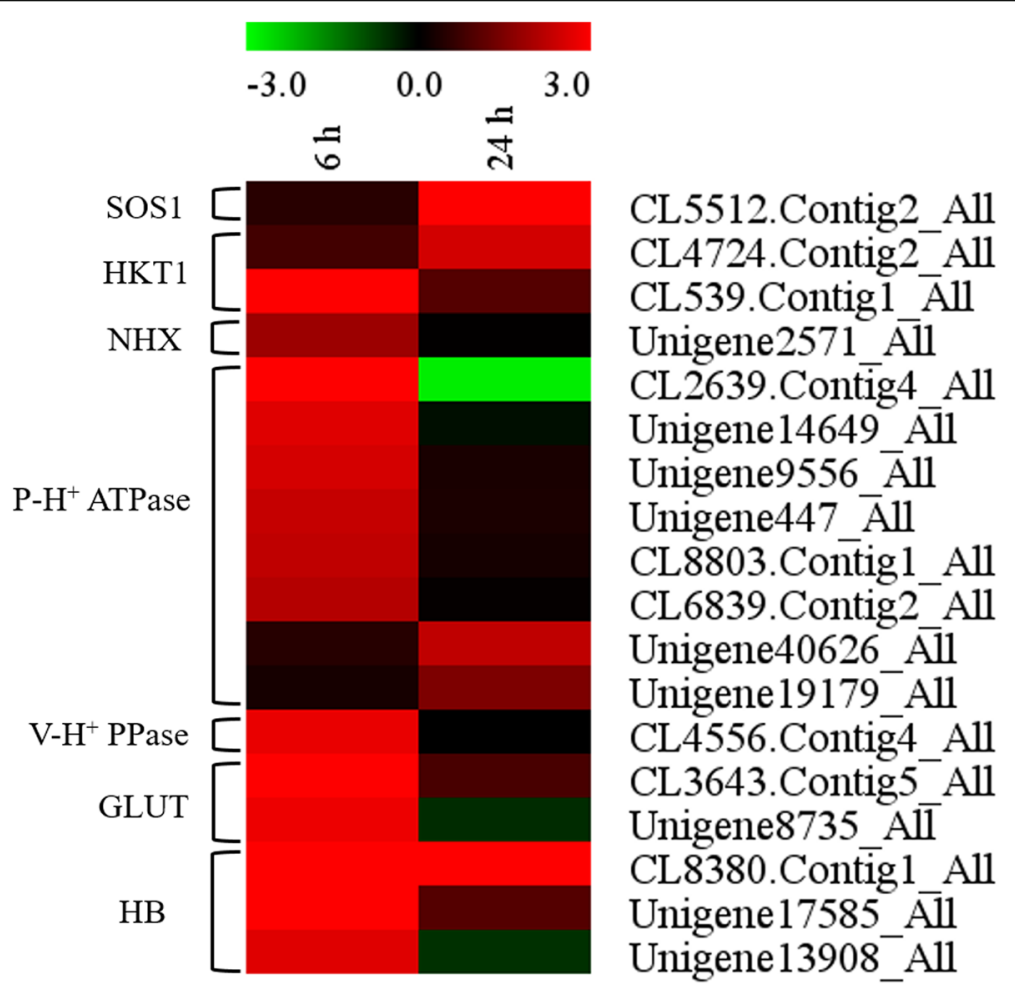

Fig. 3 Heatmap of DEGs related to $\mathrm{Na}^{+}, \mathrm{H}^{+}$, glucose transporters and hemoglobin in leaves of A. canescens under $100 \mathrm{mM} \mathrm{NaCl}$ for 6 and $24 \mathrm{~h}$ 
bladder cells and the oxygen is used for oxidative phosphorylation, these two processes both help to produce ATP for $\mathrm{Na}^{+}$sequestration [65]. Our results showed that upregulated DEGs in leaves under $100 \mathrm{mM} \mathrm{NaCl}$ also included 2 GLUTs and 3 HBs (Fig. 3).

In roots, the number of upregulated DEGs was much lower than that of downregulated DEGs when plants were treated with $100 \mathrm{mM} \mathrm{NaCl}$ for $6 \mathrm{~h}$ (Fig. 4a). These upregulated DEGs included important genes involved in the transport of $\mathrm{Na}^{+}, \mathrm{K}^{+}, \mathrm{Ca}^{2+}$ (such as NHX, KT/HAK/ KUP and CNGC), $\mathrm{Mg}^{2+}(M G T), \mathrm{NH}_{4}{ }^{+}(A M T), \mathrm{NO}^{3-}$ (NRT), $\mathrm{SO}_{4}{ }^{2-}\left(\right.$ STAS), $\mathrm{PO}_{4}{ }^{3-}(P H T)$ and several important micronutrients, and $4 \mathrm{H}^{+}$-pump genes were also upregulated (Fig. 4a; Additional file 1: Table S5). After plants were treated with $100 \mathrm{mM} \mathrm{NaCl}$ for $24 \mathrm{~h}$, the number of upregulated DEGs remained stable, but the number of downregulated DEGs was significantly lower than that under treatment for $6 \mathrm{~h}$ (Fig. $4 \mathrm{a}$ and b). Most of these upregulated genes are involved in the transport of $\mathrm{K}^{+}$(AKT and KT/HAK/KUP), $\mathrm{Ca}^{2+}(C N G C), \mathrm{NH}_{4}^{+}$ $(A M T)$ and $\mathrm{NO}^{3-}$ (NRT); additionally, 4 P- $H^{+}$ATPases and $1 \mathrm{~V}-\mathrm{H}^{+}$PPase genes were upregulated (Fig. 4b; Additional file 1: Table S6). More importantly, the transcripts levels of 8 DEGs involved in $\mathrm{K}^{+}$transport were upregulated in roots under $100 \mathrm{mM} \mathrm{NaCl}$ but not under control conditions for either 6 or $24 \mathrm{~h}$ (Table 2).

\section{DEGs related to organic osmolyte synthesis}

The accumulation of highly compatible solutes in leaves is another important reason why $A$. canescens has a high tolerance to harsh saline conditions. Thus, the DEGs related to the synthesis of organic osmolytes (including proline, betaine and soluble sugar) in the leaves of $A$. canescens under $100 \mathrm{mM} \mathrm{NaCl}$ were identified.

There were 35 and 21 upregulated DEGs and 23 and 9 downregulated DEGs related to organic osmolytes accumulation in leaves when plants were treated with 100 $\mathrm{mM} \mathrm{NaCl}$ for 6 and $24 \mathrm{~h}$, respectively (Fig. $5 \mathrm{a}$ and b). When plants were treated with $100 \mathrm{mM} \mathrm{NaCl}$ for $6 \mathrm{~h}$, the upregulated DEGs included important enzyme genes related to proline production (P5CS, OAT, GDH and GOGAT), betaine synthesis (BADH and $C M O)$ and soluble carbohydrate accumulation (such as INV, SuSy and TPS) (Fig. 5a; Additional file 1: Table S7). Likewise, many genes encoding enzymes related to the synthesis of organic osmolytes mentioned above were also

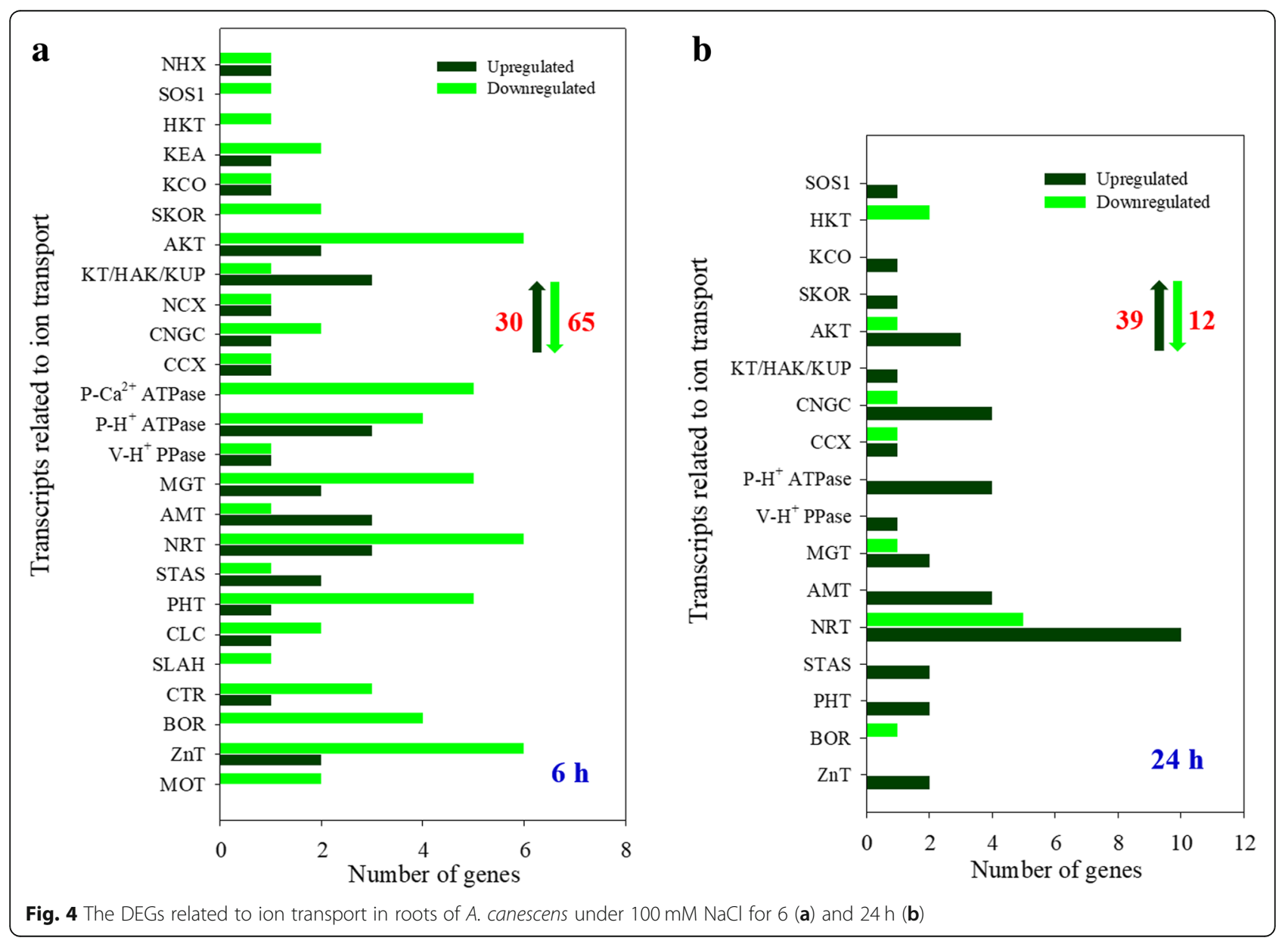



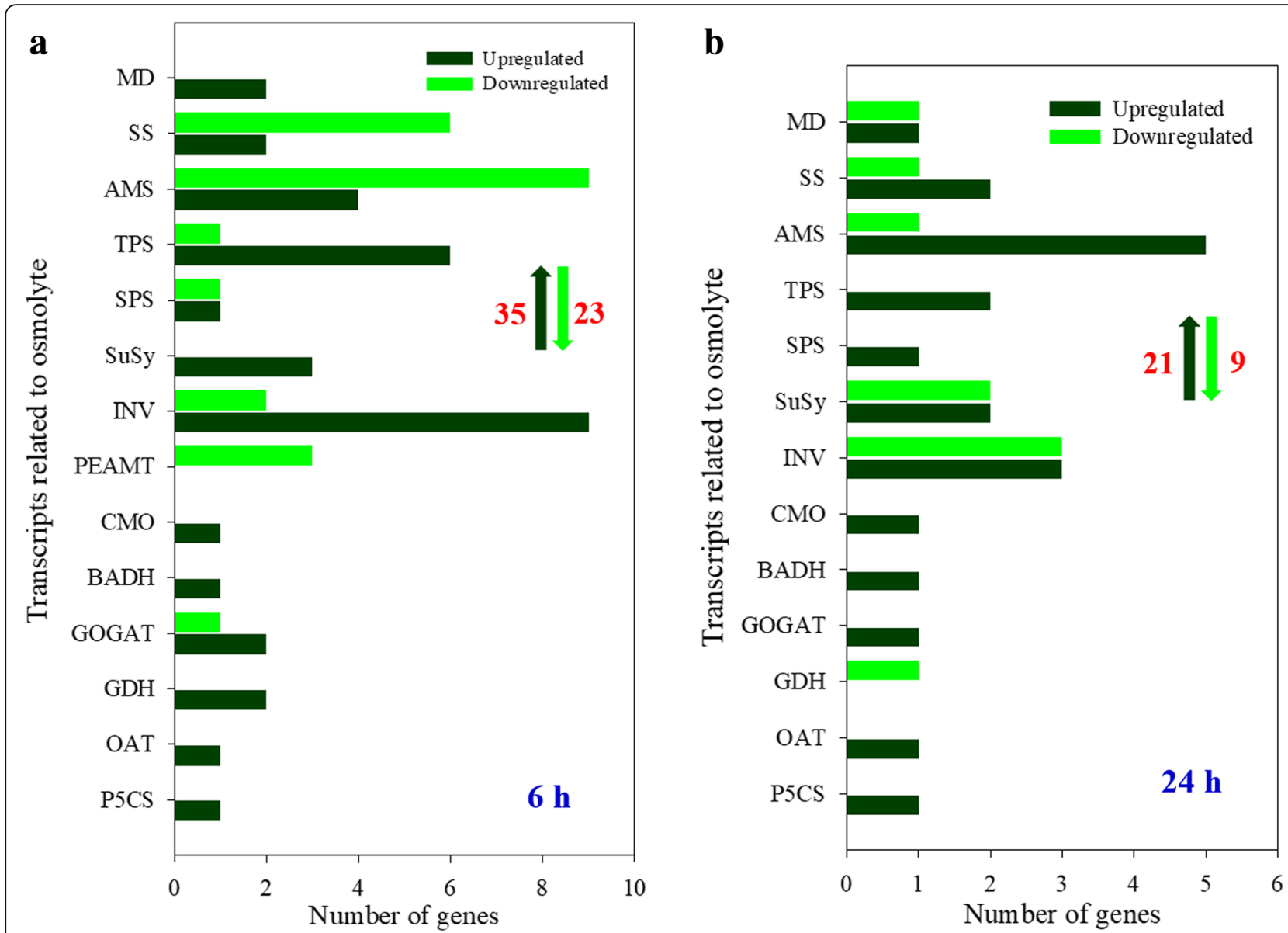

Fig. 5 The DEGs related to organic osmolytes synthesis in leaves of $A$. canescens under $100 \mathrm{mM} \mathrm{NaCl}$ for 6 (a) and 24h (b). P5CS: $\Delta 1$-pyrroline-5carboxylate synthetase, OAT: ornithine aminotransferase, GDH: glutamate dehydrogenase, GOGAT: glutamate synthase, BADH: betaine aldehyde dehydrogenase, CMO: choline monooxygenase, PEAMT: phosphoethanolamine N-methyltransferase, INV: invertase, SuSy: sucrose synthase, SPS: sucrose-phosphate synthase, TPS: trehalose-phosphate synthase, AMS: amylase, SS: starch synthase, MD: mannitol dehydrogenase. The up and down arrows indicate the total number of up and downregulated DEGs, respectively

upregulated by treatment with $100 \mathrm{mM} \mathrm{NaCl}$ for $24 \mathrm{~h}$ (Fig. 5b; Additional file 1: Table S8). Moreover, the transcripts levels of 2, 2 and 9 genes involved in accumulating proline, betaine and soluble sugar, respectively, showed a significant increase in leaves under $100 \mathrm{mM}$ $\mathrm{NaCl}$ treatment for both 6 and $24 \mathrm{~h}$ (Table 3).

\section{DEGs related to water transport}

To understand how A. canescens maintains water balance under saline conditions, we analyzed the DEGs related to aquaporin (AQP) in the leaves of $A$. canescens exposed to the $100 \mathrm{mM} \mathrm{NaCl}$ treatment. In total, 24 AQP genes were found in A. canescens under $100 \mathrm{mM}$ $\mathrm{NaCl}$, including 11 NIP, 2 SIP, 4 PIP and 6 TIP genes (Fig. 6). After treatment with $100 \mathrm{mM} \mathrm{NaCl}$ for $6 \mathrm{~h}$, there were 6,1, 2 and 3 upregulated DEGs categorized into the gene families listed above, respectively, and when plants were treated with $100 \mathrm{mM} \mathrm{NaCl}$ for $24 \mathrm{~h}$, the number of upregulated DEGs was obviously lower than that in plants treated for $6 \mathrm{~h}$ (Fig. 6). Among these AQP genes, interestingly, 12 genes showed upregulated expression in leaves but were downregulated in the roots under $100 \mathrm{mM} \mathrm{NaCl}$ for $6 \mathrm{~h}$. For example, the transcripts of the tonoplast aquaporin gene TIP2;2 (Unigene15728_All) dramatically increased by more than 14 times in leaves but decreased by 12 times in roots (Table 4).

\section{DEGs related to photosynthesis}

Higher photosynthetic capacity is also an important strategy for $A$. canescens adaptation to saline environments. Therefore, the DEGs related to photosynthesis under $100 \mathrm{mM} \mathrm{NaCl}$ were identified. The number of upregulated DEGs was much lower than that of downregulated DEGs after treatment with $100 \mathrm{mM} \mathrm{NaCl}$ for $6 \mathrm{~h}$, and the upregulated DEGs included 1, 1, 1, 2, 1 and 14 genes related to photosystem II, the component of cytochrome $b 6 / f$ complex, photosystem I, ferredoxin, 
Table 3 The upregulated DEGs related to organic osmolytes synthesis in leaves of A. canescens under $100 \mathrm{mM} \mathrm{NaCl}$ for both 6 and $24 \mathrm{~h}$

\begin{tabular}{lll}
\hline Involved process & Gene ID & Homologous gene \\
\hline Proline production & Unigene27678_All & Pyrroline-5-carboxylate synthetase P5CS \\
Betaine synthesis & CL9819.Contig4_All & Glutamate synthase GOGAT \\
Sucrose accumulation & CL8998.Contig2_All & Betaine aldehyde dehydrogenase BADH \\
& CL1302.Contig2_All & Choline monooxygenase CMO \\
& CL879.Contig1_All & Exocellular acid invertase INV \\
Amylolysis & CL796.Contig1_All & Sucrose synthase SuSy2 \\
& CL1644.Contig3_All & Sucrose synthase SuSy7 \\
Trehalose synthesis & CL9220.Contig3_All & Sucrose-phosphate synthase SPS \\
Mannitol synthesis & CL2655.Contig3_All & B-amylase AMS4 \\
& CL6110.Contig1_All & B-amylase AMS7 \\
& Unigene1043_All & Trehalose-phosphate synthase TPS \\
\hline
\end{tabular}

thylakoid membrane ATP synthase and the enzymes involved in carbon fixation, respectively (Fig. 7a; Additional file 1: Table S9). When plants were treated with $100 \mathrm{mM} \mathrm{NaCl}$ for $24 \mathrm{~h}$, the number of upregulated DEGs remained stable, and the number of downregulated DEGs decreased sharply from 108 to 12 compared with that under treatment for $6 \mathrm{~h}$, and there were $2,1,4,2,9$, 2 and 1 upregulated DEGs related to the component of photosystem II, cytochrome $b 6 / f$ complex, photosystem I, ATP synthase, enzymes related to carbon fixation, chlorophyll biosynthesis and chlorophyll catabolism, respectively (Fig. 7b; Additional file 1: Table S10). Then, we analyzed these upregulated DEGs in depth and found that 5 and 9 upregulated DEGs (including 2 phosphoenolpyruvate carboxylase, 2 malate dehydrogenase, 2 malic enzyme and 3 aspartate aminotransferase) were involved in the process of photosynthetic electron transport and the $\mathrm{C}_{4}$ carbon fixation pathway, respectively, under $100 \mathrm{mM} \mathrm{NaCl}$ treatment for $6 \mathrm{~h}$ (Table 5), indicating that these genes are likely to provide prerequisites for the improvement of photosynthetic capacity of $A$. canescens under saline conditions. In addition, the transcripts of 2, 6 and 4 DEGs involved in the process of chlorophyll biosynthesis, photosynthetic electron transport and the enzymes associated with carbon fixation, respectively, were significantly upregulated after treated with $100 \mathrm{mM} \mathrm{NaCl}$ for $24 \mathrm{~h}$ but not for $6 \mathrm{~h}$ (Table 5).

\section{Validation of the DEGs}

To further verify the reliability of the transcriptome analysis results, 30 DEGs closely related to this study were randomly selected for qRT-PCR analysis. And all the primers for $\mathrm{qPCR}$ were required to amplify single fragments with the expected lengths (100-250 bp, data not shown). The fold changes in relative gene expression measured by qRT-PCR were consistent with the corresponding transcript abundance changes detected by RNA-Seq (Additional file 1:Table S11 and 12). And the linear regression analysis of the fold changes between RNA-Seq and qRT-PCR results exhibited a high correlation, with $R^{2}=0.88$ and 0.89 in leaves, respectively, under $100 \mathrm{mM} \mathrm{NaCl}$ for $6 \mathrm{~h}$ (Additional file 1: Figure S4a) and 24h (Additional file 1: Figure S4b), as well as $R^{2}=0.91$ and 0.90 in roots, respectively, under $100 \mathrm{mM}$ $\mathrm{NaCl}$ for $6 \mathrm{~h}$ (Additional file 1: Figure S4c) and $24 \mathrm{~h}$ (Additional file 1: Figure S4d), indicating that the RNA-Seq results were highly reliable.

\section{Discussion}

An efficient ion transport system is a crucial factor in $A$. canescens response to salt

Halophytes depend mostly on the utilization of inorganic ions (such as $\mathrm{Na}^{+}$and $\mathrm{K}^{+}$) to maintain shoot osmotic potential and turgor pressure under saline conditions [43]. Ion transport is a crucial factor affecting salt tolerance in plants, playing a fundamental role in homeostasis, signaling and development, particularly in certain halophytes [12, 51]. As a representative secretohalophyte, A. canescens possesses unique morphological characteristics (salt bladders) supporting its adaptation to saline environments. Our previous study showed that A. canescens could accumulate a great quantity of $\mathrm{Na}^{+}$in leaf tissues as well as salt bladders for OA and could maintain the stability of $\mathrm{K}^{+}$concentration by improving the transport capacity of $\mathrm{K}^{+}$over that of $\mathrm{Na}^{+}$from the stem to leaf under saline conditions, indicating that $A$. canescens could effectively regulate $\mathrm{Na}^{+} / \mathrm{K}^{+}$homeostasis [40]. Thus, the transcripts of genes related to ion 


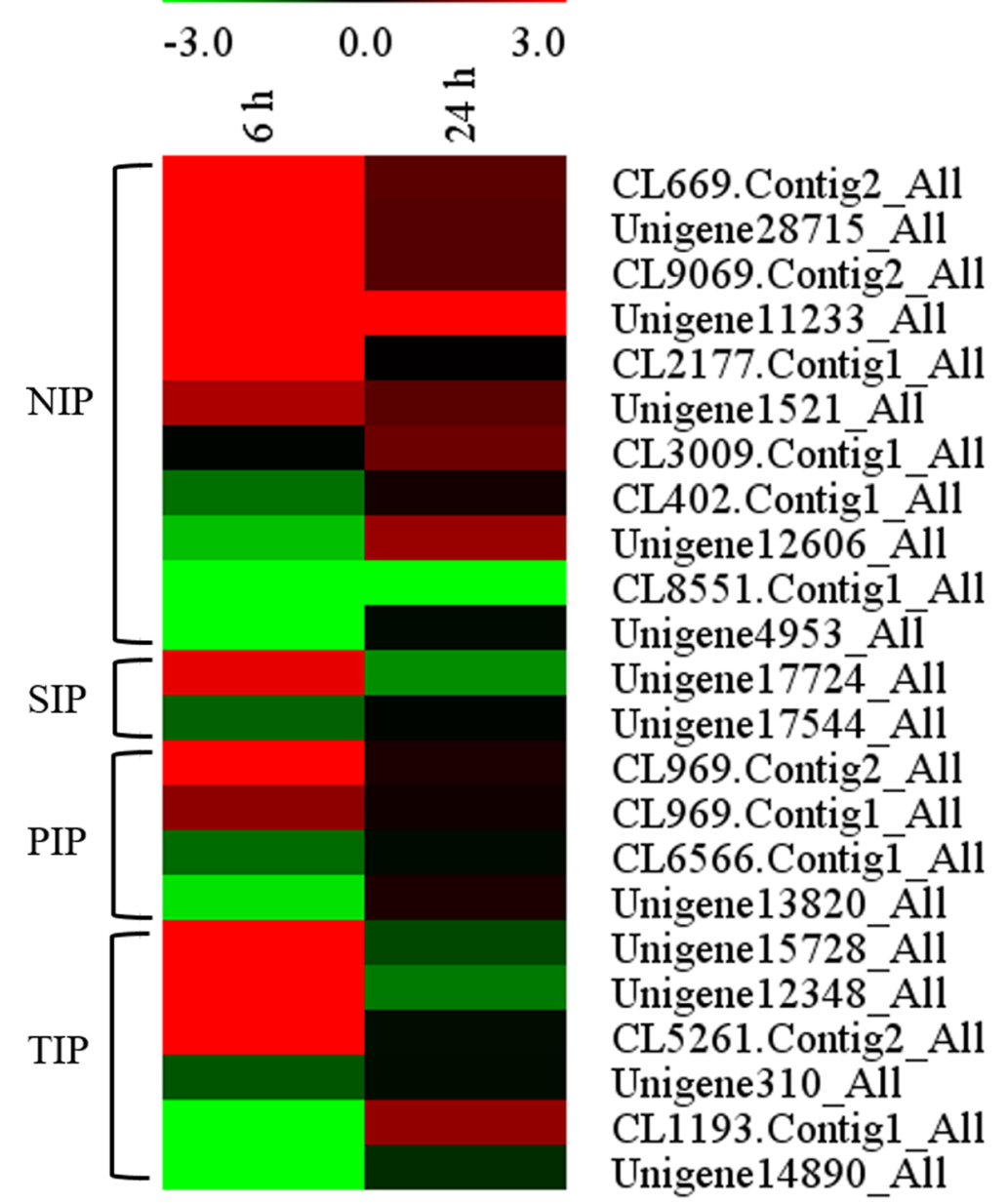

Fig. 6 Heatmap of the transcript level of genes related to aquaporin in A. canescens under $100 \mathrm{mM} \mathrm{NaCl}$ treatment for 6 and $24 \mathrm{~h}$. NIP: nodulinlike intrinsic protein, SIP: small basic intrinsic protein, PIP: plasma membrane intrinsic protein, TIP: tonoplast intrinsic protein. The same below

transport is most likely to play an important role in the adaptation of this species to saline conditions.

Leaves are the main organs of salt accumulation for the secretohalophyte $A$. canescens, which is capable of depositing large quantities of salt in EBCs on the leaf surface [40]. How this plant transports and sequesters $\mathrm{Na}^{+}$into EBCs is not clear. The plasma membrane $\mathrm{Na}^{+}$/ $\mathrm{H}^{+}$antiporter SOS1 mediates cellular $\mathrm{Na}^{+}$efflux [64]. Previous studies found that salt treatment could induce the preferential expression of AtSOS1 at the root tip, excluding $\mathrm{Na}^{+}$from the root and thereby reducing the absorption of $\mathrm{Na}^{+}$[46]. The high-affinity $\mathrm{K}^{+}$transporter HKT1 mediates cellular $\mathrm{Na}^{+}$influx, and HKT1 in Arabidopsis has been demonstrated to unload $\mathrm{Na}^{+}$from xylem vessels to parenchyma cells and/or control the retrieval of $\mathrm{Na}^{+}$from the xylem to reduce the amount of $\mathrm{Na}^{+}$reaching shoots $[9,49]$. Moreover, SOS1 and HKT1 mediate the opposite $\mathrm{Na}^{+}$fluxes under salt treatment to synergistically regulate $\mathrm{Na}^{+}$transport and homeostasis
[31]. In addition, the tonoplast $\mathrm{Na}^{+} / \mathrm{H}^{+}$antiporter $\mathrm{NHX}$ has been proven to compartmentalize $\mathrm{Na}^{+}$into vacuoles, and overexpression of NHX could reduce the cytosolic $\mathrm{Na}^{+}$concentration and improve salt tolerance by efficient sequestration [42]. In this study, the transcript levels of AcSOS1 (CL5512.Contig2_All), AcHKT1 (CL4724.Contig2_All and CL539.Contig1_All) and AcNHX (Unigene2571_All) in leaves were significantly higher under $100 \mathrm{mM} \mathrm{NaCl}$ than in the control (Figs. 2 and 3; Additional file 1: Tables S3 and S4), excitedly, SOS1 and HKT1 in A. canescens were different from in other plants located in roots $[9,47]$. Therefore, the excess $\mathrm{Na}^{+}$in the leaves of $A$. canescens is likely to secrete into EBCs via these proteins, that is, $\mathrm{Na}^{+}$is excluded from leaf ECs, probably by SOS1; passed by stalk cells (SCs); and then loaded into EBCs likely by HKT1; finally, $\mathrm{Na}^{+}$may be sequestered in vacuoles by NHX. Recent research has proved that $H K T 1 ; 2$ expressed in leaves and the EBCs of C. quinoa mediates inward $\mathrm{Na}^{+}$currents, 
Table 4 Aquaporin genes upregulated in leaves but downregulated in roots of A. canescens under $100 \mathrm{mM} \mathrm{NaCl}$ for $6 \mathrm{~h}$. "Fold change in leaves" equals $\log _{2}$ (FPKM-SL6/FPKM-CL6) and "Fold change in roots" equals $\log _{2}$ (FPKM-SR6/FPKM-CR6)

\begin{tabular}{llll}
\hline Gene ID & Homlogous gene & Fold change in leaves & Fold change in roots \\
\hline CL669.Contig2_All & NIP4;1 & 11.62 & -11.17 \\
Unigene28715_All & NIP5;1 & 9.85 & -3.84 \\
CL9069.Contig2_All & NIP5;1 & 7.71 & -8.41 \\
Unigene11233_All & NIP5;1 & 6.70 & -5.64 \\
CL2177.Contig1_All & NIP1;2 & 4.05 & -4.17 \\
Unigene1521_All & NIP1;2 & 2.01 & -1.76 \\
Unigene17724_All & SIP1;2 & 2.72 & -1.77 \\
CL969.Contig2_All & PIP2;1 & 3.04 & -3.11 \\
CL969.Contig1_All & PIP1;2 & 1.69 & -1.02 \\
Unigene15728_All & TIP2;2 & 14.24 & -12.17 \\
Unigene12348_All & TIP4;1 & 4.89 & -4.87 \\
CL5261.Contig2_All & TIP1;3 & 4.87 & -4.84 \\
\hline
\end{tabular}

which is responsible for loading the $\mathrm{Na}^{+}$into the EBCs [4], strongly supporting our speculation that the AcHKT1 expressed in leaves directly participated in $\mathrm{Na}^{+}$ accumulation in EBCs under saline conditions. In addition, when these proteins transport $\mathrm{Na}^{+}$from ECs into EBCs, plasma- and tonoplast-based $\mathrm{H}^{+}$pumps are required to generate an $\mathrm{H}^{+}$electrochemical gradient [31, 65]. In our study, $100 \mathrm{mM} \mathrm{NaCl}$ significantly induced the transcripts of $8 P$ - $H^{+}$-ATPases and $1 \mathrm{~V}$ - $H^{+}$-PPase in leaves (Fig. 3), which might provide a proton pump for secondary transmembrane active transport. In addition,
2 GLUTs in the leaves were upregulated by $\mathrm{NaCl}$, which might unidirectionally move glucose from the mesophyll into EBCs to fuel the above-mentioned $\mathrm{H}^{+}$pumps, and 3 HBs probably facilitated oxygen diffusion into SCs/EBCs to be used for oxidative phosphorylation and ATP production (Fig. 3) [65]. Our data indicate that there is an efficient mechanism in the leaves of $A$. canescens for transporting and sequestering $\mathrm{Na}^{+}$, and most importantly, maintaining ion homeostasis under saline conditions by regulating the transcripts of important genes involved in $\mathrm{Na}^{+}$transport.
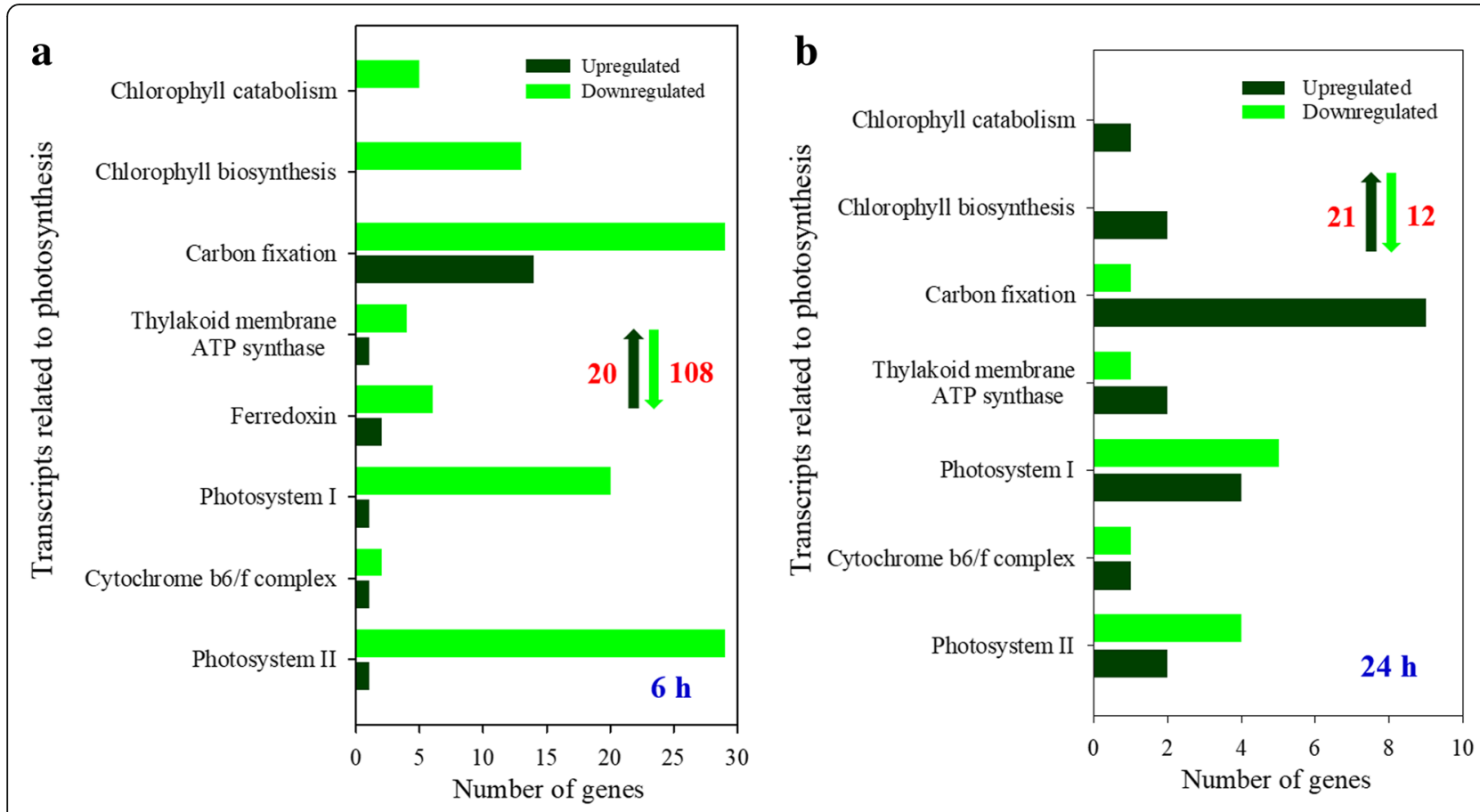

Fig. 7 The DEGs related to photosynthesis of $A$. canescens under $100 \mathrm{mM} \mathrm{NaCl}$ for 6 (a) and $24 \mathrm{~h}$ (b) 
Table 5 The upregulated DEGs related to photosynthesis of A. canescens under $100 \mathrm{mM} \mathrm{NaCl}$. The genes upregulated at $6 \mathrm{~h}$ are shaded in red, and the genes upregulated at $24 \mathrm{~h}$ but not at $6 \mathrm{~h}$ are shaded in blue

\begin{tabular}{|c|c|c|c|c|}
\hline Involved process & Gene ID & Homologous gene & $\begin{array}{l}\log _{2} \text { Ratio } \\
\text { (SL6/CL6) }\end{array}$ & $\begin{array}{l}\log _{2} \text { Ratio } \\
\text { (SL24/CL24) }\end{array}$ \\
\hline \multirow[t]{5}{*}{ Electron transport } & Unigene31059_All & Photosystem II 10 kDa polypeptide & 6.71 & - \\
\hline & Unigene14296_All & NADPH-quinone oxidoreductase & 1.80 & -0.25 \\
\hline & Unigene40452_All & Cytochrome b6/f complex subunit VIII & 6.04 & -5.95 \\
\hline & Unigene5352_All & Ferredoxin-NADP reductase & 4.57 & -0.32 \\
\hline & Unigene6812_All & Ferredoxin-3 & 1.92 & -0.47 \\
\hline \multirow[t]{9}{*}{$C_{4}$ carbon fixation } & CL2649.Contig3_All & Phosphoenolpyruvate carboxylase & 2.14 & 0.25 \\
\hline & CL6760.Contig2_All & Phosphoenolpyruvate carboxylase & 1.44 & 0.28 \\
\hline & Unigene34895_All & Malate dehydrogenase & 5.13 & 1.01 \\
\hline & CL6022.Contig2_All & Malate dehydrogenase & 1.42 & -0.16 \\
\hline & CL6958.Contig4_All & NADP-dependent malic enzyme & 3.84 & 1.63 \\
\hline & CL7555.Contig1_All & NAD-dependent malic enzyme & 1.57 & 0.09 \\
\hline & CL791.Contig2_All & Aspartate aminotransferase & 1.94 & 1.58 \\
\hline & CL8006.Contig1_All & Aspartate aminotransferase & 1.14 & 0.47 \\
\hline & CL7761.Contig1_All & Aspartate aminotransferase & 1.12 & 0.25 \\
\hline \multirow[t]{2}{*}{ Chlorophyll biosynthesis } & Unigene31043_All & Protoporphyrinogen oxidase & -0.06 & 1.28 \\
\hline & CL8468.Contig2_All & Protoporphyrinogen oxidase & 0.34 & 7.90 \\
\hline \multirow[t]{6}{*}{ Electron transport } & CL4550.Contig3_All & Chlorophyll a-b binding protein & -8.16 & 1.05 \\
\hline & Unigene173_All & Photosystem II CP43 chlorophyll apoprotein & -0.63 & 1.03 \\
\hline & Unigene7017_All & Cytochrome f & 0.68 & 1.58 \\
\hline & Unigene10241_All & Photosystem I P700 apoprotein A2 & -2.71 & 1.39 \\
\hline & Unigene18662_All & photosystem I P700 apoprotein A2 & -1.74 & 1.68 \\
\hline & Unigene25839_All & Photosystem I reaction center subunit & - & 7.17 \\
\hline \multirow[t]{4}{*}{ Carbon fixation } & CL1287.Contig1_All & Malate dehydrogenase [NADP] & -5.27 & 2.90 \\
\hline & Unigene26311_All & Ribulose 1,5-bisphosphate carboxylase & -5.81 & 5.73 \\
\hline & Unigene10116_All & Ribulose 1,5-bisphosphate carboxylase & -0.58 & 1.99 \\
\hline & CL4619.Contig1_All & Alanine aminotransferase 2 & -2.15 & 1.20 \\
\hline
\end{tabular}

The accumulation and secretion of a large amount of $\mathrm{Na}^{+}$in leaves facilitate the absorption and transport of $\mathrm{Na}^{+}$. Some proteins have been proven to be involved in $\mathrm{Na}^{+}$uptake. A $\mathrm{Na}^{+} / \mathrm{Ca}^{2+}$ exchanger-like protein (NCX, also named NCL) from Arabidopsis probably mediates $\mathrm{Na}^{+}$uptake, since the content of total $\mathrm{Na}^{+}$in atncl mutants was obviously lower than that in wild-type (WT) seedlings under salt stress [54]. The cyclic nucleotide-gated channels (CNGCs) may also participate in $\mathrm{Na}^{+}$uptake in Arabidopsis; AtCNGC3 and AtCNGC10 were preferentially expressed in the epidermal and endodermal cells in roots, and the knockout of these two genes, respectively, decreased the net $\mathrm{Na}^{+}$influx in roots under salt stress $[20,23]$. In $A$. canescens, $1 N C X$ and 4 CNGCs were significantly induced by $100 \mathrm{mM} \mathrm{NaCl}$, especially the transcript level of 1 CNGC (Unigene12729_All, highly homologous to CNGC4), which was significantly increased under $100 \mathrm{mM} \mathrm{NaCl}$ for both 6 and $24 \mathrm{~h}$ but not under control conditions (Fig. 4;
Additional file 1: Tables S5 and S6). These genes might provide an effective pathway for $\mathrm{Na}^{+}$uptake in A. canescens under $\mathrm{NaCl}$ treatment. After entering the endodermis, $\mathrm{Na}^{+}$would be loaded into the xylem and then transported to the shoot with the transpiration stream. The plasma membrane $\mathrm{Na}^{+} / \mathrm{H}^{+}$antiporter SOS1 controls long-distance $\mathrm{Na}^{+}$transport [47], and Zygophyllum xanthoxylum ZxSOS1-silenced plants exhibit inhibition of growth due to accumulating more $\mathrm{Na}^{+}$in roots but less $\mathrm{Na}^{+}$in leaves and stems than WT plants under salt treatment [33]. The present study found that the transcript abundance of the gene encoding AcSOS1 (CL5512.Contig2_All) in roots was significantly increased under $100 \mathrm{mM} \mathrm{NaCl}$ for $24 \mathrm{~h}$ (Fig. 4b; Additional file 1: Table S6), indicating that this gene might participate in the long-distance transport of $\mathrm{Na}^{+}$from the roots to shoots in A. canescens.

Our previous study showed that $A$. canescens could maintain intracellular $\mathrm{K}^{+}$homeostasis under salt 
treatment [40]. Numerous studies have identified a series of proteins involved in $\mathrm{K}^{+}$uptake and transport. The inwardly rectifying $\mathrm{K}^{+}$channel AKT1 was not only correlated with $\mathrm{K}^{+}$uptake in roots but also related to $\mathrm{Na}^{+}$ homeostasis under saline conditions, and overexpression of $A K T 1$ improved salt tolerance of transgenic plants by increasing tissue levels of $\mathrm{K}^{+}$[32]. Moreover, the stelar $\mathrm{K}^{+}$outwardly rectifying channel (SKOR) mediates long-distance $\mathrm{K}^{+}$transport and plays an important role in $\mathrm{K}^{+}$accumulation and homeostasis under salt stress [29]. The knockout mutant atskor exhibited both lower shoot $\mathrm{K}^{+}$content and lower xylem sap $\mathrm{K}^{+}$concentration compared to WT plants, indicating that SKOR participated in $\mathrm{K}^{+}$release into the xylem sap toward the shoots [16]. The high-affinity $\mathrm{K}^{+}$transporter HAK5 in Arabidopsis participates in $\mathrm{K}^{+}$acquisition and translocation from roots to shoots, and its expression is remarkably upregulated under both $\mathrm{K}^{+}$starvation and salt stress conditions, playing key roles in $\mathrm{OA}$ by maintaining $\mathrm{K}^{+}$ homeostasis in stress responses [60]. Furthermore, CNGC proteins also mediate $\mathrm{K}^{+}$uptake and transport, and both atcngc3 and atcngc10 mutants exhibited lower $\mathrm{K}^{+}$accumulation than WT under salt stress $[20,23]$. In A. canescens, the transcripts levels of many DEGs related to $\mathrm{K}^{+}$transport were upregulated (Figs. 2 and 4; Additional file 1: Tables S3-S6); in particular, 8 and 9 genes were expressed in the roots and leaves under $100 \mathrm{mM}$ $\mathrm{NaCl}$ but not under control conditions for either 6 or $24 \mathrm{~h}$, respectively (Table 2). Among these 8 genes in the roots, 2 AKT1s, 2 CNGCs and 1 HAK might be involved in $\mathrm{K}^{+}$acquisition in roots; 1 SKOR gene might mediate long-distance transport of $\mathrm{K}^{+}$from the root to shoot in A. canescens. The 9 genes in leaves still included $1 \mathrm{KEA}$ and $1 K C O$ in addition to the $A K T, S K O R$ and CNGC families. The $\mathrm{K}^{+}$efflux antiporters (KEAs) are mainly located in plastid-containing organisms and related to chloroplast development and regulation of $\mathrm{pH}$ homeostasis, playing an important role in the regulation of monovalent cation efflux to maintain ion homeostasis in plant cells [1]. The two-pore $\mathrm{K}^{+}$channel $\mathrm{KCO}$ (also named TPK) localized in the tonoplast is beneficial for maintaining intracellular $\mathrm{K}^{+}$homeostasis by regulating vacuolar $\mathrm{K}^{+}$concentration [19]. Therefore, A. canescens possesses an efficient molecular mechanism for modulating $\mathrm{K}^{+}$homeostasis in response to saline conditions.

It is necessary for higher plants to regulate the balance of various nutrients, in addition to $\mathrm{Na}^{+} / \mathrm{K}^{+}$homeostasis, in saline environments. In this study, we found that 100 $\mathrm{mM} \mathrm{NaCl}$ significantly induced the transcripts of genes encoding proteins that participate in the uptake and transport of important nutrient elements, such as $\mathrm{Ca}^{2+}$ (CNGC, cation/Ca ${ }^{2+}$ exchanger $\mathrm{CCX}$ and plasma membrane $\mathrm{Ca}^{2+}$-ATPase), $\mathrm{Mg}^{2+}$ (magnesium transporter MGT), $\mathrm{NH}_{4}{ }^{+}$(ammonium transporter $\mathrm{AMT}$ ), $\mathrm{NO}^{3-}$ (nitrate transporter NRT), $\mathrm{PO}_{4}{ }^{3-}$ (phosphate transporter $\mathrm{PHT}$ ) and $\mathrm{SO}_{4}{ }^{2-}$ (sulfate transporter STAS) (Figs. 2 and 4; Additional file 1: Tables S3-S6). Notably, the transcript levels of genes encoding proteins involved in the transport of micronutrient elements were also upregulated in A. canescens, and they are mainly involved in the transport of $\mathrm{Cu}^{2+}$ (copper transporter CTR), $\mathrm{BO}^{3-}$ (boron transporter $\mathrm{BOR}$ ), $\mathrm{Zn}^{3+}$ (zinc transporter $\mathrm{ZnT}$ ), and $\mathrm{MoO}_{4}{ }^{2-}$ (molybdate transporter MOT) (Figs. 2 and 4; Additional file 1: Tables S3-S6). Therefore, A. canescens could enhance the absorption and transport of nutrient elements by increasing the transcripts of genes encoding transporters/channels for important macro- and microelements to regulate the balance of various nutrients.

\section{Organic osmolyte accumulation is indispensable for $A$. canescens adaptation to salinity}

Under saline conditions, the production of organic osmoprotectants is an important aspect of salt tolerance for higher plants. Our physiological studies have shown that the accumulation of a large amount of compatible solutes (including proline, glycine betaine and soluble sugar) in leaves is an important mechanism of adaptation to saline conditions for $A$. canescens [40]; Guo $\mathrm{H}$. and Bao A.K., unpublished data). Studies have shown that $\Delta 1$-pyrroline-5-carboxylate synthetase (P5CS) is a key rate-limiting enzyme in the pathway for proline biosynthesis, and P5CS genes in Arabidopsis play crucial roles in stress regulation and developmental control of proline biosynthesis; atp $5 c s 1$ mutants showed a decrease in stress-induced proline synthesis, resulting in high sensitivity to salt stress and accumulation of reactive oxygen species [50, 58]. Moreover, glutamate (Glu) synthase (GOGAT) plays an important role in the synthesis of Glu, which is an important precursor of proline synthesis and is strongly correlated with proline accumulation [35]. Betaine aldehyde dehydrogenase (BADH) and choline monooxygenase (CMO) are the most critical enzymes catalyzing the synthesis of glycine betaine, and overexpression of the $C M O$ and $B A D H$ genes enhances salt tolerance in transgenic plants [48]. In addition, $B A D H$ has been characterized in $A$. canescens, and transforming $A c B A D H$ into soybean improved the salt and drought tolerance of transgenic plants; the higher yield of transgenic lines than of WT plants is particularly exciting [41]. Invertase (INV), sucrose synthase (SuSy) and sucrose phosphate synthase (SPS) are essential enzymes in sucrose metabolism [3, 37]; furthermore, tomato regulates the activity of these enzymes by controlling the expression patterns of their genes to adapt to salinity [30]. Amylase (AMS), mannitol dehydrogenase (MD) and trehalose-6-phosphate synthase (TPS) play indispensable roles in starch, mannitol and trehalose metabolism, respectively, and their enzyme 
activities are positively related to the salt tolerance of plants [7]. In this study, multiple genes encoding key enzymes for the synthesis of proline, betaine and soluble sugar in leaves were upregulated under $100 \mathrm{mM} \mathrm{NaCl}$ (Fig. 5; Additional file 1: Tables S7-S8), and 13 genes (such as P5CS, BADH and SPS) of these upregulated genes were continuously expressed under salt treatment for both 6 and $24 \mathrm{~h}$ (Table 3), suggesting that A. canescens possesses an efficient mechanism for accumulating osmoprotectants under saline conditions by modulating the expression patterns of important genes involved in compatible solute biosynthesis, which would be conducive to protecting plants in saline environments by OA.

\section{Aquaporin plays an important role in the regulation of water balance in $A$. canescens under saline conditions}

A. canescens seedlings can maintain a higher leaf relative water content by effective OA under salinity treatment [40]. Moreover, our latest study found that water was abundantly transported as a solvent into salt bladders with the accumulation of $\mathrm{Na}^{+}$in salt bladders of $A$. canescens under $\mathrm{NaCl}$ treatment, causing rapid expansion of the salt bladders, a sharp increase in turgor pressure and eventually the bursting of the bladders and subsequent release of a large amount of accumulated $\mathrm{Na}^{+}$(Guo H. and Bao A.K., unpublished data); this finding suggests that the rapid accumulation of water in salt bladders is the key factor affecting salt secretion in $A$. canescens. AQPs can effectively regulate the water balance inside and outside of the plant cell by specifically mediating the rapid transmembrane transport of water [6]. In this study, many DEGs related to AQPs were upregulated in leaves but not in roots under $100 \mathrm{mM} \mathrm{NaCl}$ for $6 \mathrm{~h}$, including 6 nodulin-like intrinsic proteins (NIPs), 1 small basic intrinsic protein (SIP), 2 plasma membrane intrinsic proteins (PIPs) and 3 tonoplast intrinsic proteins (TIPs) (Table 4). The NIPs mainly mediate boron uptake (NIP5;1) or are involved in pollen development and pollination (NIP4) in Arabidopsis thaliana [10, 55]. The SIPs are localized to the endoplasmic reticulum membrane but currently are not well characterized [25]. Plasma membrane-located PIPs are divided into the PIP1 and PIP2 groups; PIP2 members mainly function as water channels, while PIP1 members usually have much lower or no water conductivity due to their failure to localize to the plasma membrane [5]. Our results showed that the transcript of 1 PIP gene (CL969.Contig2_All, highly homologous to PIP2;3) was significantly upregulated in leaves (Table 4). PIP2 in Malus zumi Mats is involved in water movement during both water absorption and transport and alters the salt tolerance of transgenic Arabidopsis [53]. An AQP protein, AcPIP2, characterized from $A$. canescens, improved plant growth rate and salt tolerance when overexpressed in $A$. thaliana [28]. Moreover, tonoplast-located TIPs, primarily mediating the accumulation of water in the vacuole, play vital roles in maintaining cell turgor and enhancing the capacity for OA and are also able to indirectly promote $\mathrm{Na}^{+}$compartmentation into vacuoles, which is conducive to improving plant adaptation to saline environments $[25,36]$. In the present study, we found that the transcripts of 3 TIPs (Unigene15728_All, highly homologous to TIP2;2; Unigene12348_All, highly homologous to TIP4;1 and CL5261.Contig2_All, highly homologous to TIP1;3) were sharply upregulated in the leaves but downregulated in the roots of $A$. canescens under $\mathrm{NaCl}$ treatment, and there was even a 14.24-fold increase in the transcript level of AcTIP2;2 (Table 4). Therefore, the AcPIP2 and AcTIPs in the leaves of $A$. canescens are likely to be involved in the transport of water into salt bladders under salt treatment, which facilitates salt secretion and the maintenance of the water balance in leaves and might result from the accumulation of solutes in leaf tissues and salt bladders.

\section{Moderate salinity improves photosynthesis of $A$. canescens by increasing the transcripts of photosynthesis- related genes}

Previous studies showed that $\mathrm{NaCl}$ significantly improved the photosynthetic capacity of A. canescens plants, and the trends of photosynthetic indicators were different from those of $\mathrm{C}_{3}$ xerohalophytes, suggesting that $\mathrm{Na}^{+}$may promote the $\mathrm{C}_{4}$ photosynthetic process of A. canescens under saline conditions [40]. $C_{4}$ plants share stronger $\mathrm{CO}_{2}$ assimilation capacity and can sufficiently utilize light energy; moreover, this kind of plant have greater adaptability to adversity since they can take advantage of low $\mathrm{CO}_{2}$ levels in the intercellular space under stress conditions [15, 27]. The oxygenic photosynthesis of higher plants can be divided into three stages: the primary reaction, photosynthetic electron transport and photophosphorylation and $\mathrm{CO}_{2}$ assimilation. The first two steps in this process involve the conversion of sunlight into active chemical energy, which is driven by several multisubunit membrane protein complexes, including photosystem II, cytochrome $b 6 / f$, photosystem I, ferredoxin and ATP synthase [38]. The last reaction is a process that converts $\mathrm{CO}_{2}$ into stable chemical energy stored in organic matter by using the energy (ATP and $\mathrm{NADPH}$ ) produced by the light reaction [15]. Our study found that the majority of DEGs related to the above-mentioned complexes and the enzymes involved in carbon fixation and chlorophyll biosynthesis/catabolism were downregulated under $100 \mathrm{mM} \mathrm{NaCl}$ for $6 \mathrm{~h}$ (Fig. 7a, Additional file 1: S13), but the few upregulated genes were mainly involved in electron transport and carbon fixation, the latter of which were almost always involved in the $\mathrm{C}_{4}$ pathway, including phosphoenolpyruvate 
carboxylase (PEPC), malate dehydrogenase (MDH), malic enzyme (ME) and aspartate aminotransferase (AST) (Table 5). These enzymes play key roles in the $\mathrm{C}_{4}$ photosynthetic pathway and are capable of providing more $\mathrm{CO}_{2}$ for the $\mathrm{C}_{3}$ pathway in the vascular bundle sheath ${ }^{61}$. Interestingly, the transcript levels of many DEGs involved in the processes of chlorophyll biosynthesis, electron transport and carbon fixation (based on the $\mathrm{C}_{3}$ pathway) were significantly upregulated after treatment with $100 \mathrm{mM}$ $\mathrm{NaCl}$ for $24 \mathrm{~h}$ but not after treatment for $6 \mathrm{~h}$ (Table 5), suggesting that $A$. canescens preferentially increased the transcript abundances of genes encoding key enzymes in the $\mathrm{C}_{4}$ pathway to improve its assimilation capacity and then increased the transcript levels of other genes encoding complexes related to chlorophyll biosynthesis, electron transport and $\mathrm{C}_{3}$ carbon fixation under salt treatment, which might be one of the important reasons the photosynthesis of $A$. canescens was significantly improved by $100 \mathrm{mM} \mathrm{NaCl}$ [40]. At present, re-engineering $\mathrm{C}_{3}$ plants with $\mathrm{C}_{4} \mathrm{CO}_{2}$-concentrating mechanisms is of broad interest $[34,45]$. Overexpression of plastidic ZmNADP-MDH (NADP-MDH) in maize conferred salt tolerance to transgenic Arabidopsis [24]. Thus, the results of this study provide abundant genetic resources for improving photosynthetic efficiency in $\mathrm{C}_{3}$ crops/forages through genetic engineering.

\section{Conclusions}

This study identified candidate genes showing significant transcriptional changes in A. canescens under $100 \mathrm{mM}$ $\mathrm{NaCl}$ treatment, mainly focusing on genes related to ion transport, organic osmolyte synthesis, water transport and photosynthesis. The abundance of transcripts encoding transporters/channels for important macro- and microelements was significantly increased by $100 \mathrm{mM}$ $\mathrm{NaCl}$, which is conducive to promote the uptake and transport of nutrient elements. It is worth noting that some genes related to $\mathrm{Na}^{+}$transport in leaves (such as AcSOS1, AcHKT1 and AcNHX) might play crucial roles in the excretion of salt via epidermis bladder cells. In addition, the transcripts of a number of genes related to the synthesis of organic osmolytes in leaves was significantly upregulated by $\mathrm{NaCl}$ treatment, which allowed the accumulation of more organic solutes to enhance $\mathrm{OA}$ under salt treatment. Moreover, $100 \mathrm{mM} \mathrm{NaCl}$ promoted water transport in $A$. canescens by inducing the transcripts of aquaporin-encoding genes in leaves. Interestingly, $\mathrm{NaCl}$ preferentially induced the transcripts of genes encoding proteins participating in the $\mathrm{C}_{4}$ photosynthetic pathway to provide greater assimilation capacity for photosynthesis and then increased the transcript levels of other genes encoding complexes related to chlorophyll biosynthesis, electron transport and $\mathrm{C}_{3}$ carbon fixation under salt treatment. Our results lay the foundation for investigating molecular mechanisms of salt tolerance in secretohalophytes and provide a theoretical basis for genetic improvement of stress tolerance in important crops and forages by using the outstanding gene resources from $A$. canescens.

\section{Methods \\ Plant materials and experimental treatments}

Seeds of Atriplex canescens were collected from Lingwu County in Ningxia Autonomous Region, China. After removed the hard seed coat with $75 \% \mathrm{H}_{2} \mathrm{SO}_{4}(\mathrm{v} / \mathrm{v})$ for 15 $h$, the seeds were washed many times with purified water until the washings has no smell and then germinated in moist vermiculite at $28^{\circ} \mathrm{C}$ in the dark for 5 days. Uniform seedlings were transplanted into plastic containers $(5 \mathrm{~cm} \times 5 \mathrm{~cm} \times 5 \mathrm{~cm}$; two plants/pot) filled with vermiculite and irrigated with 1/2-strength Hoagland nutrient solution at 2-day intervals [40]. Plants were cultured at $28{ }^{\circ} \mathrm{C} / 25^{\circ} \mathrm{C}$ (day/night), $16 / 8 \mathrm{~h}$ photoperiod (light/dark; the light density was approximately $800 \mu \mathrm{mol} / \mathrm{m}^{2} / \mathrm{s}$ ) and $65 \%$ relative humidity.

Four-week-old seedlings were treated with 1/ 2-strength Hoagland nutrient solution supplemented with 0 (control) or $100 \mathrm{mM} \mathrm{NaCl}$. The leaves and roots of seedlings in the two treatments were collected after treatment for 6 and $24 \mathrm{~h}$, respectively. A total of eight samples were marked as follows: CL6, CR6, SL6, SR6, CL24, CR24, SL24 and SR24; C and S represent the control and treatment with $100 \mathrm{mM} \mathrm{NaCl}$, respectively; 6 and 24 denote the treatment duration; and $\mathrm{R}$ and $\mathrm{L}$ denote the roots and leaves, respectively. For example, SL6 and SR6 were the leaf and root samples, respectively, from salt-treated plants for which seedlings were treated for $6 \mathrm{~h}$. All the fresh samples were immediately frozen in liquid nitrogen and stored at $-80^{\circ} \mathrm{C}$ until RNA extraction.

\section{RNA preparation, CDNA library construction and Illumina sequencing}

Total RNA was isolated from the eight samples with an RNeasy Plant Mini Kit (Qiagen). The extracted RNA was quantified by using a NanoDrop ND-1000 instrument (Thermo Scientific), and the integrity of the RNA was determined by $1 \%$ agarose gel electrophoresis. Equivalent amounts of total RNA isolated from each of the four leaf tissues (CL6, SL6, CL24 and SL24) and each of the four corresponding root tissues (CR6, SR6, CR24 and SR24) were pooled. The two mRNA pools were then used for reverse transcription to obtain two cDNA libraries as the cDNA in the leaves and roots of A. canescens by using the method described by Dang et al. [8] and sequenced on an Illumina HiSeq ${ }^{\mathrm{Tw}} 2000$ platform in BGI Shenzhen. 


\section{De novo assembly and functional annotation}

High-quality clean reads were created after filtering adaptor sequences, duplicated sequences, reads containing more than $5 \%$ ambiguous bases ('N') and reads in which more than $50 \%$ of bases showed a $Q$-value $\leq 5$. After filtering out low quality reads, de novo assembly was proceeded by using Trinity; then, the Trinity unigenes were clustered with TGICL software to minimize sequence redundancy [21]. The unigenes were divided into two classes after performing gene family clustering, one class included clusters with the prefix CL contained several unigenes with a sequence similarity of more than $70 \%$, and the other included singletons with the prefix unigenes [31]. To attach predicted gene informations for assembled unigenes, the sequences were functionally annotated based on seven protein databases (including the Nr, Nt, Swiss-Prot, Kyoto Encyclopedia of Genes and Genomes (KEGG), Clusters of Orthologous Groups (COG), InterPro and Gene Ontology (GO) databases) using the BLASTX tool with an $E$-value $\leq 10^{-5}$ threshold. Blast2GO software was employed to perform functional categorization by GO terms on the basis of biological process, cellular component and molecular function ontologies, and the Web Gene Ontology Annotation Plot (WEGO) tool was used to statistically analyze the data [8].

\section{Differentially expressed gene (DEG) library preparation and analysis}

Eight independent cDNA libraries (CL6, CR6, SL6, SR6, CL24, CR24, SL24 and SR24) were prepared in parallel for leaves and roots at different times under salt treatment by using a tag-based DGE kit [59]. Then, each library was sequenced through the Illumina $\mathrm{HiSeq}^{\mathrm{Tw}} 2000$ sequencing platform in BGI Shenzhen. After low-quality reads (including reads with adaptors, more than $10 \%$ unknown nucleotides ('N') and only one copy number) were removed, the clean reads were mapped to the transcriptome reference database. And then, the transcript levels of all assembled unigenes were calculated by using the number of fragments per $\mathrm{kb}$ per million reads (FPKM) method to identify differentially expressed genes (DEGs) [59]. In addition, the false discovery rate (FDR) method was used to confirm the threshold $P$-value for multiple tests and analysis by manipulating the FDR value. An FDR $<0.001$ and an absolute value of $\mid \log _{2} \mathrm{Ra}$ tio $\mid>1$ were used as thresholds to identify DEGs [8].

\section{qRT-PCR validation of DEGs}

To experimentally evaluate the RNA-Seq results, total RNA was extracted from the 8 samples as described before and reversely transcribed into cDNA according to the manufacturer's protocol (TaKaRa Biotechnology). The qRT-PCR was conducted by using SYBR Green
Real-Time PCR Master Mix (TaKaRa Biotechnology) and performed on a StepOnePlus Real-Time PCR Thermocycler (Applied Biosystems, USA). ACTIN gene was used as the internal standard. The relative transcript levels of the 30 randomly selected unigenes were calculated using the $2^{-\Delta \Delta \mathrm{Ct}}$ method [31].

\section{Additional file}

\begin{abstract}
Additional file 1 : Figure S1. Length distribution of all assembled unigenes. Figure S2. COG function distribution of all unigenes. A total of 26,012 putative proteins showing significant homology to those in the COG database were classified into 25 functional clusters. X-axis indicates the number of unigenes in a cluster. Figure S3. GO function distribution of all unigenes. A total of 37,395 unigenes were assigned to GO terms and were summarized in 3 main GO categories and 52 subcategories. Xaxis indicates the number of genes in a category. Figure S4. Correlation analysis for expression pattern validation of 30 randomly selected DEGs between RNA-Seq and qRT-PCR results. Table S1. Summary of sequencing reads after filtering. Table S2. Summary of sequence annotation. Table S3. Differentially expressed genes (DEGs) related to ion transport in leaves of $A$. canescens under $100 \mathrm{mM} \mathrm{NaCl}$ for $6 \mathrm{~h}$. Table S4. DEGs related to ion transport in leaves of $A$. canescens under $100 \mathrm{mM} \mathrm{NaCl}$ for $24 \mathrm{~h}$. Table S5. DEGs related to ion transport in roots of $A$. canescens under $100 \mathrm{mM} \mathrm{NaCl}$ for $6 \mathrm{~h}$. Table S6. DEGs related to ion transport in roots of $A$. canescens under $100 \mathrm{mM} \mathrm{NaCl}$ for $24 \mathrm{~h}$. Table S7. DEGs related to organic osmolytes synthesis in leaves of $A$. canescens under $100 \mathrm{mM}$ $\mathrm{NaCl}$ for $6 \mathrm{~h}$. Table S8. DEGs related to organic osmolytes synthesis in leaves of $A$. canescens under $100 \mathrm{mM} \mathrm{NaCl}$ for $24 \mathrm{~h}$. Table S9. DEGs related to photosynthesis in leaves of $A$. canescens under $100 \mathrm{mM} \mathrm{NaCl}$ for $6 \mathrm{~h}$. Table S10. DEGs related to photosynthesis in leaves of A. canescens under $100 \mathrm{mM} \mathrm{NaCl}$ for $24 \mathrm{~h}$. Table S11. Expression pattern validation of 30 randomly selected genes in leaves of $A$. canescens under $100 \mathrm{mM} \mathrm{NaCl}$ for 6 and $24 \mathrm{~h}$ by qRT-PCR. Table S12. Expression pattern validation of 30 randomly selected genes in roots of $A$. canescens under $100 \mathrm{mM} \mathrm{NaCl}$ for 6 and $24 \mathrm{~h}$ by qRT-PCR. (DOCX $1081 \mathrm{~kb})$
\end{abstract}

\section{Abbreviations}

AKT: Inwardly rectifying $\mathrm{K}^{+}$channel; AMS: Amylase; $\mathrm{AMT} \mathrm{NH}_{4}{ }^{+}$transporter; $\mathrm{BADH}$ : Betaine aldehyde dehydrogenase; $\mathrm{BOR}$ : $\mathrm{BO}^{3-}$ transporter; $\mathrm{CCX}$ : Cation/ $\mathrm{Ca}^{2+}$ exchanger; $\mathrm{CLC}$ : Vacuolar $\mathrm{Cl}^{-} / \mathrm{H}^{+}$exchanger; $\mathrm{CMO}$ : Choline monooxygenase; CNGC: Cyclic nucleotide-gated channel; COG: Clusters of orthologous groups; CTR: $\mathrm{Cu}^{2+}$ transporter; DEG: Differentially expressed gene; EBC: Epidermal bladder cell; EC: Epidermal cell; FDR: False discovery rate; FPKM: Number of transcripts per million clean reads; GDH: Glutamate dehydrogenase; GLUT: Glucose transporter; GO: Gene ontology; GOGAT: Gluamate synthase; HB: Hemoglobin; HKT: High-affinity $\mathrm{K}^{+}$ transporter; INV: Invertase; KEGG: Kyoto encyclopedia of genes and genomes; KT/HAK/KUP: $\mathrm{K}^{+}$transporter; MD: Mannitol dehydrogenase; MGT: $\mathrm{Mg}^{2+}$ transporter; MOT: $\mathrm{MoO}_{4}{ }^{2-}$ transporter; $\mathrm{NHX}$ : Tonoplast $\mathrm{Na}^{+} / \mathrm{H}^{+}$antiporter; NIP: Nnodulin-like intrinsic protein; $\mathrm{NRT}_{\mathrm{N}} \mathrm{NO}_{3}{ }^{-}$transpoter; OAT: Ornithine aminotransferase; P5CS: $\Delta$ 1-pyrroline-5-carboxylate synthetase; $\mathrm{P}-\mathrm{Ca}^{2+}$ ATPase: Plasma membrane $\mathrm{Ca}^{2+}$ ATPase; PEAMT: Phosphoethanolamine $\mathrm{N}$ methyltransferase; $\mathrm{P}-\mathrm{H}^{+}$ATPase: Plasma membrane $\mathrm{H}^{+}$ATPase; $\mathrm{PHT}$ : $\mathrm{PO}_{4}{ }^{3-}$ transporter; PIP: Plasma membrane intrinsic protein; SC: Stalk cell; SIP: Small basic intrinsic protein; SKOR: Stelar $\mathrm{K}^{+}$outward rectifying channel; SLAH: Slow type anion channel; SOS1: Plasma membrane $\mathrm{Na}^{+} / \mathrm{H}^{+}$antiporter;

SPS: Sucrose-phosphate synthase; SS: Starch synthase; STAS: $\mathrm{SO}_{4}{ }^{2-}$ transporter; SuSy: Sucrose synthase; TIP: Tonoplast intrinsic protein; TPS: Trehalose-phosphate synthase; $V$-CAX: Vacuolar cation $/ H^{+}$exchanger; $V$ $\mathrm{H}^{+}$PPase: Vacuolar $\mathrm{H}^{+}$PPase; $\mathrm{ZnT}$ : $\mathrm{Zn}^{3+}$ transporter

\section{Acknowledgements}

We thank all the members in our laboratory for providing useful discussions. We are very grateful to Dr. Shelley Roanne Hepworth from Carleton University, Canada, for valuable suggestions. 


\section{Funding}

This work was supported by the National Natural Science Foundation of China (31730093; 31670405), the National Key Research and Development Program of China (2017YFC0504804), and the Fundamental Research Funds for the Central Universities (Izujbky-2018-k01). Funds were used for the design of the study, collection, analysis, and interpretation of data and in writing the manuscript, as well as in the open access payment.

\section{Availability of data and materials}

The datasets used and/or analyzed during the current study are available from the corresponding author upon reasonable request.

\section{Authors' contributions}

$A-K B$ and $H G$ conceived and designed the study. $H G$ and $L Z$ performed the experiments. HG, LZ and Y-NC collected and analyzed data. HG wrote the manuscript. S-MW, A-KB and $\mathrm{Y}-\mathrm{NC}$ revised the manuscript. All author read and approved the final manuscript.

\section{Ethics approval and consent to participate}

Not applicable.

\section{Consent for publication}

Not applicable.

\section{Competing interests}

The authors declare that they have no competing interests.

\section{Publisher's Note}

Springer Nature remains neutral with regard to jurisdictional claims in published maps and institutional affiliations.

\section{Received: 28 February 2019 Accepted: 9 May 2019}

\section{Published online: 22 May 2019}

\section{References}

1. Aranda-Sicilia MN, Cagnac O, Chanroj S, Sze H, Rodriguez-Rosales MP, Venema K. Arabidopsis KEA2, a homolog of bacterial KefC, encodes a $\mathrm{K}^{+} / \mathrm{H}^{+}$ antiporter with a chloroplast transit peptide. Biochim Biophys Acta. 2012; 1818:2362-71.

2. Bao AK, Du BQ, Touil L, Kang P, Wang QL, Wang SM. Co-expression of tonoplast cation/ $\mathrm{H}^{+}$antiporter and $\mathrm{H}^{+}$-pyrophosphatase from xerophyte Zygophyllum xanthoxylum improves alfalfa plant growth under salinity, drought and field conditions. Plant Biotechnol J. 2016;14:964-75.

3. Barratt DHP, Derbyshire P, Findlay K, Pike M, Wellner N, Lunn J, Feil R, Simpson C, Maule AJ, Smith AM. Normal growth of Arabidopsis requires cytosolic invertase but not sucrose synthase. Proc Natl Acad Sci U S A. 2009; 106:13124-9.

4. Böhm J, Messerer M, Müller HM, Scholz-Starke J, Gradogna A, Scherzer S, Maierhofer T, Bazihizina N, Zhang H, Stigloher C, Ache P, Al-Rasheid KAS, Mayer KFX, Shabala S, Carpaneto A, Haberer G, Zhu JK, Hedrich R. Understanding the molecular basis of salt sequestration in epidermal bladder cells of Chenopodium quinoa. Curr Biol. 2018;28:1-11.

5. Chaumont F, Barrieu F, Jung R, Chrispeels MJ. Plasma membrane intrinsic proteins from maize cluster in two sequence subgroups with differential aquaporin activity. Plant Physiol. 2000;122:1025-34

6. Chaumont F, Tyerman SD. Aquaporins: highly regulated channels controlling plant water relations. Plant Physiol. 2014;164:1600-18.

7. Conde A, Regalado A, Rodrigues D, Costa JM, Blumwald E, Chaves MM, Gerós H. Polyols in grape berry: transport and metabolic adjustments as a physiological strategy for water-deficit stress tolerance in grapevine. J Exp Bot. 2015;66:889-906.

8. $\quad$ Dang ZH, Zheng LL, Wang J, Gao Z, Wu SB, Qi Z, Wang YC. Transcriptomic profiling of the salt-stress response in the wild recretohalophyte Reaumuria trigyna. BMC Genomics. 2013;14:29

9. Davenport RJ, Munoz-Mayor A, Jha D, Essah PA, Rus A, Tester M. The $\mathrm{Na}^{+}$ transporter AtHKT1 controls retrieval of $\mathrm{Na}^{+}$from the xylem in Arabidopsis. Plant Cell Environ. 2007;30:497-507.

10. Di Giorgio JAP, Bienert GP, Ayub ND, Yaneff A, Barberini ML, Mecchia MA, Amodeo G, Soto GC, Muschiettia JP. Pollen-specific aquaporins NIP4;1 and NIP4;2 are required for pollen development and pollination in Arabidopsis thaliana. Plant Cell. 2016;28:1053-77.
11. Ding F, Yang JC, Yuan F, Wang BS. Progress in mechanism of salt excretion in recretohalopytes. Front Biol. 2010;5:164-70.

12. Flowers TJ, Colmer TD. Plant salt tolerance: adaptations in halophytes. Ann Bot. 2015;115:327-31.

13. Flowers TJ, Galal HK, Bromham L. Evolution of halophytes: multiple origins of salt tolerance in land plants. Funct Plant Biol. 2010;37:604-12.

14. Flowers TJ, Munns R, Colmer TD. Sodium chloride toxicity and the cellular basis of salt tolerance in halophytes. Ann Bot. 2015;115:419-31.

15. Furbank RT. Evolution of the $C_{4}$ photosynthetic mechanism: are there really three $C_{4}$ acid decarboxylation types? J Exp Bot. 2011;62:3103-8.

16. Gaymard F, Pilot G, Lacombe B, Bouchez D, Bruneau D, Boucherez J, Michaux-Ferrière $\mathrm{N}$, Thibaud J, Sentenac $\mathrm{H}$. Identification and disruption of a plant shaker-like outward channel involved in $\mathrm{K}^{+}$release into the xylem sap. Cell. 1998;94:647-55.

17. Glenn EP, Olsen M, Frye R, Moore D, Miyamoto S. How much sodium accumulation is necessary for salt tolerance in subspecies of the halophyte Atriplex canescens? Plant Cell Environ. 1994:17:711-9.

18. Glenn EP, Pfister R, Brown JJ, Thompson TL, O'Leary J. Na and K accumulation and salt tolerance of Atriplex canescens (Chenopodiaceae) genotypes. Am J Bot. 1996;83:997-1005

19. Gobert A, Isayenkov S, Voelker C, Czempinski K, Maathuis FJ. The two-pore channel TPK1 gene encodes the vacuolar $\mathrm{K}^{+}$conductance and plays a role in $\mathrm{K}^{+}$homeostasis. Proc Natl Acad Sci U S A. 2007;104:10726-31.

20. Gobert A, Park G, Amtmann A, Sanders D, Maathuis FJM. Arabidopsis thaliana cyclic nucleotide gated channel 3 forms a nonselective ion transporter involved in germination and cation transport. J Exp Bot. 2006;57:791-800.

21. Grabherr MG, Haas BJ, Yassour M, Levin JZ, Thompson DA, Amit I, Adiconis X, Fan L, Raychowdhury R, Zeng QD, Chen ZH, Mauceli E, Hacohen N, Gnirke A, Rhind N, Palma FD, Birren BW, Nusbaum C, Lindblad-Toh K, Friedman N, Regev A. Full-length transcriptome assembly from RNA-Seq data without a reference genome. Nat Biotechnol. 2011;29:644-52.

22. Hao GY, Lucero ME, Sanderson SC, Zacharias EH, Holbrook NM. Polyploidy enhances the occupation of heterogeneous environments through hydraulic related trade-offs in Atriplex canescens (Chenopodiaceae). New Phytol. 2013;197:970-8.

23. Jin $Y K$, Jing W, Zhang Q, Zhang WH. Cyclic nucleotide gated channel 10 negatively regulates salt tolerance by mediating $\mathrm{Na}^{+}$transport in Arabidopsis. J Plant Res. 2015;128:211-20.

24. Kandoi D, Mohanty S, Tripathy BC. Overexpression of plastidic maize NADPmalate dehydrogenase ( $Z m N A D P-M D H)$ in Arabidopsis thaliana confers tolerance to salt stress. Protoplasma. 2017;255:547-63.

25. Kayum MA, Park Jl, Nath UK, Biswas MK, Kim HT, Nou IS. Genome-wide expression profiling of aquaporin genes confer responses to abiotic and biotic stresses in Brassica rapa. BMC Plant Biol. 2017;17:23.

26. Kiani-Pouya A, Roessner U, Jayasinghe NS, Lutz A, Rupasinghe T, Bazihizina N, Bohm J, Alharbi S, Hedrich R, Shabala S. Epidermal bladder cells confer salinity stress tolerance in the halophyte quinoa and Atriplex species. Plant Cell Environ. 2017:40:1900-15.

27. Kustka AB, Milligan AJ, Zheng H, New AM, Gates C, Bidle KD, Reinfelder JR. Low $\mathrm{CO}_{2}$ results in a rearrangement of carbon metabolism to support $\mathrm{C}_{4}$ photosynthetic carbon assimilation in Thalassiosira pseudonana. New Phytol. 2015;204:507-20.

28. Li JT, Yu G, Sun XH, Liu YZ, Liu JL, Zhang XH, Jia CG, Pan HY. AcPIP2, a plasma membrane intrinsic protein from halophyte Atriplex canescens, enhances plant growth rate and abiotic stress tolerance when overexpressed in Arabidopsis thaliana. Plant Cell Rep. 2015;34:1401-15.

29. Liu K, Li LG, Luan S. Intracellular $K^{+}$sensing of $S K O R$, a shaker-type $K^{+}$ channel from Arabidopsis. Plant J. 2006;46:260-8.

30. Lu SW, Li TL, Jiang J. Effects of salinity on sucrose metabolism during tomato fruit development. Afr J Biotechnol. 2010;9:842-9.

31. Ma Q, Bao AK, Chai WW, Wang WY, Zhang JL, Li YX, Wang SM. Transcriptomic analysis of the succulent xerophyte Zygophyllum xanthoxylum, in response to salt treatment and osmotic stress. Plant Soil. 2016a:402:343-61.

32. Ma Q, Hu J, Zhou XR, Yuan HJ, Kumar T, Luan S, Wang SM. ZXAKT1 is essential for $\mathrm{K}^{+}$uptake and $\mathrm{K}^{+} / \mathrm{Na}^{+}$homeostasis in the succulent xerophyte Zygophyllum xanthoxylum. Plant J. 2016b;90:48-60.

33. Ma Q, Li YX, Yuan HJ, Hu J, Wei L, Bao AK, Zang JL, Wang SM. ZXSOS1 is essential for long-distance transport and spatial distribution of $\mathrm{Na}^{+}$and $\mathrm{K}^{+}$in the xerophyte Zygophyllum xanthoxylum. Plant Soil. 2014;374:661-76 
34. Mackinder $\mathrm{LCM}$. The chlamydomonas $\mathrm{CO}_{2}$-concentrating mechanism and its potential for engineering photosynthesis in plants. New Phytol. 2018;217:54-61.

35. Masclaux-Daubresse, Reisdorf-Cren M, Pageau K, Lelandais M, Grandjean O, Kronenberger J, Valadier MH, Feraud M, Jouglet T, Suzuki A. Glutamine synthetase-glutamate synthase pathway and glutamate dehydrogenase play distinct roles in the sink-source nitrogen cycle in tobacco. Plant Physiol. 2006;140:444-56.

36. Maurel C, Verdoucq $L$, Rodrigues $O$. Aquaporins and plant transpiration. Plant Cell Environ. 2016;39:2580-7.

37. Miron D, Schaffer AA. Sucrose phosphate synthase, sucrose synthase, and invertase activities in developing fruit of Lycopersicon esculentum mill. And the sucrose accumulating Lycopersicon hirsutum Humb. And Bonpl. Plant Physiol. 1991;95:623-7.

38. Nevo R, Charuvi D, Tsabari O, Reich Z. Composition, architecture and dynamics of the photosynthetic apparatus in higher plants. Plant J. 2012;70: 157-76.

39. Oh DH, Barkla BJ, Vera-Estrella R, Pantoja O, Lee SY, Bohnert HJ, Dassanayake M. Cell type-specific responses to salinity - the epidermal bladder cell transcriptome of Mesembryanthemum crystallinum. New Phytol. 2015;207: 627-44

40. Pan YQ, Guo H, Wang SM, Zhao BY, Zhang JL, Ma Q, Yin HJ, Bao AK. The photosynthesis, $\mathrm{Na}^{+} / \mathrm{K}^{+}$homeostasis and osmotic adjustment of Atriplex canescens in response to salinity. Front Plant Sci. 2016;7:848.

41. Qin D, Zhao CL, Liu XY, Wang PW. Transgenic soybeans expressing betaine aldehyde dehydrogenase from Atriplex canescens show increased drought tolerance. Plant Breed. 2017;136:699-709.

42. Sahoo DP, Kumar S, Mishra S, Kobayashi Y, Panda SK, Sahoo L. Enhanced salinity tolerance in transgenic mungbean overexpressing Arabidopsis antiporter (NHX1) gene. Mol Breeding. 2016;36:144

43. Shabala S. Learning from halophytes: physiological basis and strategies to improve abiotic stress tolerance in crops. Ann Bot. 2013;112:1209-21.

44. Shabala S, Bose J, Hedrich R. Salt bladders: do they matter? Trends Plant Sci. 2014;19:687-91.

45. Sharwood RE, Ghannoum O, Whitney SM. Prospects for improving $\mathrm{CO}_{2}$ fixation in $\mathrm{C}_{3}$-crops through understanding $\mathrm{C}_{4}$-rubisco biogenesis and catalytic diversity. Curr Opin Plant Biol. 2016;31:135-42.

46. Shi HZ, Ishitani M, Kim C, Zhu JK. The Arabidopsis thaliana salt tolerance gene SOS1 encodes a putative $\mathrm{Na}^{+} / \mathrm{H}^{+}$antiporter. Proc Natl Acad Sci U S A. 2000;97:6896-901.

47. Shi HZ, Quintero FJ, Pardo JM, Zhu JK. The putative plasma membrane $\mathrm{Na}^{+}$/ $\mathrm{H}^{+}$antiporter SOS1 controls long-distance $\mathrm{Na}^{+}$transport in plants. Plant Cell. 2002;14:465-77.

48. Shirasawa K, Takabe T, Takabe T, Kishitani S. Accumulation of glycinebetaine in rice plants that overexpress choline monooxygenase from spinach and evaluation of their tolerance to abiotic stress. Ann Bot. 2006;98:565-71.

49. Sunarpi HT, Motoda J, Kubo M, Yang H, Yoda K, Horie R, Chan WY, Leung HY, Hattori K, Konomi M, Osumi M, Yamagami M, Schroeder Jl, Uozumi N. Enhanced salt tolerance mediated by AtHKT1 transporter-induced $\mathrm{Na}^{+}$ unloading from xylem vessels to xylem parenchyma cells. Plant J. 2005;44: 928-38.

50. Székely G, Abrahám E, Cséplo A, Rigó G, Zsigmond L, Csiszár J, Ayaydin F, Strizhov N, Jásik J, Schmelzer E, Koncz C, Szabados L. Duplicated P5CS genes of Arabidopsis play distinct roles in stress regulation and developmental control of proline biosynthesis. Plant J. 2008;53:11-28.

51. Tang XL, Mu XM, Shao HB, Wang HY, Brestic M. Global plant-responding mechanisms to salt stress: physiological and molecular levels and implications in biotechnology. Crit Rev Biotechnol. 2015;35:425-37.

52. Wang B, Davenport RJ, Volkov V, Amtmann A. Low unidirectional sodium influx into root cells restricts net sodium accumulation in Thellungiella halophila, a salt-tolerant relative of Arabidopsis thaliana. J Exp Bot. 2006;57: 1161-70.

53. Wang L, Li QT, Lei Q, Feng C, Gao YN, Zheng XD, Zhao Y, Wang Z, Kong J. MzPIP2;1: an aquaporin involved in radial water movement in both water uptake and transportation, altered the drought and salt tolerance of transgenic Arabidopsis. PLoS One. 2015;10:e0142446.

54. Wang P, Li ZW, Wei JS, Zhao ZL, Sun DY, Cui SJ. A Na ${ }^{+} / \mathrm{Ca}^{2+}$ exchanger-like protein (AtNCL) involved in salt stress in Arabidopsis. J Biol Chem. 2012;287: 44062-70.

55. Wang SL, Yoshinari A, Shimada T, Hara-Nishimura I, Mitani-Ueno N, Ma JF, Naito S, Takano J. Polar localization of the NIP5;1 boric acid channel is maintained by endocytosis and facilitates boron transport in Arabidopsis roots. Plant Cell. 2017;29:824-42.

56. Wang SM, Zhang JL, Flowers TJ. Low affinity $\mathrm{Na}^{+}$uptake in the halophyte Suaeda maritima. Plant Physiol. 2007;145:559-71.

57. Wang Z, Gerstein M, Snyder M. RNA-Seq: a revolutionary tool for transcriptomics. Nat Rev Genet. 2009;10:57-63.

58. Wei C, Cui Q, Zhang XQ, Zhao YQ, Jia GX. Three P5CS genes including a novel one from Lilium regale play distinct roles in osmotic, drought and salt stress tolerance. J Plant Biol. 2016;59:456-66.

59. Xue J, Bao YY, Li BL, Cheng YB, Peng ZY, Liu H, Xu HJ, Zhu ZR, Lou YG, Cheng JA, Zhang CX. Transcriptome analysis of the brown planthopper Nilaparvata lugens. PLoS One. 2010;5:e14233.

60. Yang TY, Zhang S, Hu YB, Wu FC, Hu QD, Chen G, Cai J, Wu T, Moran N, Yu $\mathrm{L}, \mathrm{Xu} \mathrm{GH}$. The role of a potassium transporter OsHAK5 in potassium acquisition and transport from roots to shoots in rice at low potassium supply levels. Plant Physiol. 2014;166:945-59.

61. Yang Z, Zheng HX, Wei XC, Song J, Wang BS, Sui N. Transcriptome analysis of sweet sorghum inbred lines differing in salt tolerance provides novel insights into salt exclusion by roots. Plant Soil. 2018;430:423-39.

62. Yuan F, Lyu MJA, Leng BY, Zhu XG, Wang BS. The transcriptome of NaCltreated Limonium bicolor leaves reveals the genes controlling salt secretion of salt gland. Plant Mol Biol. 2016;91:241-56.

63. Zhang $J$, Shi HZ. Physiological and molecular mechanisms of plant salt tolerance. Photosynth Res. 2013;115:1-22.

64. Zhu M, Shabala L, Cuin TA, Huang X, Zhou M, Munns R, Shabala S. Nax loci affect SOS1-like $\mathrm{Na}^{+} / \mathrm{H}^{+}$exchanger expression and activity in wheat. J Exp Bot. 2016;67:835-44.

65. Zou CS, Chen AJ, Xiao LH, Muller HM, Ache P, Haberer G, Zhang ML, Jia W, Deng P, Huang R, Lang D, Li F, Zhan DL, Wu XY, Zhang H, Bohm J, Liu RY, Shabala S, Hedrich R, Zhu JK, Zhang H. A high-quality genome assembly of quinoa provides insights into the molecular basis of salt bladder-based salinity tolerance and the exceptional nutritional value. Cell Res. 2017;27: 1327-40.

\section{Ready to submit your research? Choose BMC and benefit from:}

- fast, convenient online submission

- thorough peer review by experienced researchers in your field

- rapid publication on acceptance

- support for research data, including large and complex data types

- gold Open Access which fosters wider collaboration and increased citations

- maximum visibility for your research: over $100 \mathrm{M}$ website views per year

At BMC, research is always in progress.

Learn more biomedcentral.com/submissions 